Article

\title{
Tri- and Mono-Nuclear Zinc(II) Complexes Based on Half- and Mono-Salamo Chelating Ligands
}

\author{
Xiu-Yan Dong, Lei Gao, Fei Wang, Yang Zhang and Wen-Kui Dong * \\ School of Chemical and Biological Engineering, Lanzhou Jiaotong University, Lanzhou 730070, China; \\ dxy568@163.com (X.-Y.D.); GaoLei19910731@163.com (L.G.); wangfei3986@163.com (F.W.); \\ zhangy8124@163.com (Y.Z.) \\ * Correspondence: dongwk@126.com; Tel.: +86-931-4938-703 \\ Academic Editor: Sławomir J. Grabowski \\ Received: 25 July 2017; Accepted: 30 August 2017; Published: 1 September 2017
}

\begin{abstract}
Two newly designed complexes, $\left[\mathrm{Zn}\left(\mathrm{L}^{1}\right)(\mathrm{EtOH})\right](\mathbf{1})$ and $\left[\left\{\mathrm{Zn}\left(\mathrm{L}^{2}\right)(\mathrm{OAc})_{2}\right\}_{2} \mathrm{Zn}\right] \cdot \mathrm{CHCl}_{3}(\mathbf{2})$ derived from salamo and half-salamo chelating ligands $\left(\mathrm{H}_{2} \mathrm{~L}^{1}\right.$ and $\left.\mathrm{HL}^{2}\right)$ have been synthesized and characterized by elemental analyses, IR and UV-VIS spectra, fluorescence spectra, and X-ray crystallography. Complex 1 shows a slightly distorted tetragonal pyramid and forms an infinite 3D supramolecular structure. All of the Zn(II) ions in complex 2 are hexa-coordinated with slightly distorted octahedral geometries. Complex 2 possesses an infinite 2D space structure. The fluorescence titration experiments were used to characterize fluorescence properties of complexes $\mathbf{1}$ and $\mathbf{2}$. And the normalized fluorescent spectra exhibit that complexes $\mathbf{1}$ and $\mathbf{2}$ have favourable fluorescent emissions in different solvents.
\end{abstract}

Keywords: salamo-type ligand; complex; synthesis; crystal structure; fluorescence properties

\section{Introduction}

As we know, Salen-type ligands $\left(\mathrm{R}-\mathrm{CH}=\mathrm{N}-\left(\mathrm{CH}_{2}\right)_{2}-\mathrm{N}=\mathrm{CH}-\mathrm{R}\right)$ and their metal complexes have been extensively investigated in modern coordination chemistry for several decades [1-5], which have been extensively investigated in potential application in biological fields [6-13], electrochemical conducts [14,15], nonlinear optical materials [16-20], magnetic materials [21-25], luminescence properties [26-32], and supramolecular architecture [33-37], and so on. Chemical modifications of substituent or functional groups in the Salen $\mathrm{N}_{2} \mathrm{O}_{2}$ ligands are effective in exchanging the structures or the main functions of complexes, such as salamo ligand, a Salen analogue, $\left(\mathrm{R}-\mathrm{CH}=\mathrm{N}-\mathrm{O}-(\mathrm{CH})_{\mathrm{n}}-\mathrm{O}-\mathrm{N}=\mathrm{CH}-\mathrm{R}\right)$ is one of the most versatile ligands and the large electronegativity of oxygen atoms is expected to strongly affect the electronic properties of the $\mathrm{N}_{2} \mathrm{O}_{2}$ coordination sphere, which can lead to different and novel structures and properties of the resulting complexes [38].

Due to the unique structure of salamo-type complexes, a study shown that it is at least 104 times more stable than salen-type complexes [39]. The $\mathrm{Zn}$ (II) ion does not produce spectroscopic or magnetic signals because of its $3 \mathrm{~d}^{10} 4 \mathrm{~s}^{0}$ electronic configuration, when the $\mathrm{Zn}(\mathrm{II})$ ion forms complexes with ligands, the complexes generally have fluorescence properties [40,41]. Although these salamo-type $\mathrm{Zn}$ (II) complexes are currently being studied and developed, the solvent effects on the salamo-type $\mathrm{Zn}$ (II) complexes are still very rare. In order to further study the syntheses, crystal structures and fluorescence properties of the $\mathrm{Zn}$ (II) complexes with the salamo-type ligands, herein, two new complexes $\left[\mathrm{Zn}\left(\mathrm{L}^{1}\right)(\mathrm{EtOH})\right](\mathbf{1})$ and $\left[\left\{\mathrm{Zn}\left(\mathrm{L}^{2}\right)(\mathrm{OAc})_{2}\right\}_{2} \mathrm{Zn}\right] \cdot \mathrm{CHCl}_{3}(\mathbf{2})$ with salamo and half-salamo ligands $\mathrm{H}_{2} \mathrm{~L}^{1}$ and $\mathrm{HL}^{2}$ have been reported, especially the study of the half-salamo ligand and its complex is reported firstly. Half-salen ligands and their metal complexes have been extensively investigated in modern coordination chemistry for a long time [42,43], but at present, no literature has shown that half-salamo ligands and their metal complexes have been synthesized. 


\section{Experimental}

\subsection{Materials and Methods}

7-Hydroxyl-4-methyl-coumarin and 3-methoxysalicylaldehyde of $98 \%$ purity were purchased from Alfa Aesar and used without further purification (New York, NY, USA). The other reagents and solvents were analytical grade reagents from Tianjin Chemical Reagent Factory (Tianjin, China).

$\mathrm{C}, \mathrm{H}$ and $\mathrm{N}$ analyses were obtained using a GmbH VarioEL V3.00 automatic elemental analysis instrument (Berlin, Germany). Elemental analyses for zinc were detected with an IRIS ER/S-WP-1 ICP atomic emission spectrometer (Berlin, Germany). Melting points were obtained by the use of a microscopic melting point apparatus made by Beijing Taike Instrument Company Limited and were uncorrected. IR spectra were recorded on a Vertex70 FT-IR spectrophotometer, with samples prepared as $\mathrm{KBr}\left(500-4000 \mathrm{~cm}^{-1}\right)$ and CsI $\left(100-500 \mathrm{~cm}^{-1}\right)$ pellets (Bruker AVANCE, Billerica, MA, USA). UV-VIS absorption spectra were recorded on a Shimadzu UV-3900 spectrometer (Shimadzu, Japan). Luminescence spectra in solution were recorded on a Hitachi F-7000 spectrometer (Shimadzu, Japan). ${ }^{1} \mathrm{H}$ NMR spectra were determined by a German Bruker AVANCE DRX-400 spectrometer (Bruker AVANCE, Billerica, MA, USA). X-ray single crystal structure determinations were carried out on a Bruker Smart Apex CCD diffractometer (Bruker AVANCE, Billerica, MA, USA).

\subsection{Synthesis of $\mathrm{H}_{2} L^{1}$}

The major reaction steps involved in the synthesis of $\mathrm{H}_{2} \mathrm{~L}^{1}$ and $\mathrm{HL}^{2}$ are given in Scheme 1 . 8-Formyl-7-hydroxy-4-methylcoumarin was prepared according to reported procedure [44]. 1,2-Bis (aminooxy)ethane was synthesized following the literature [45-47].

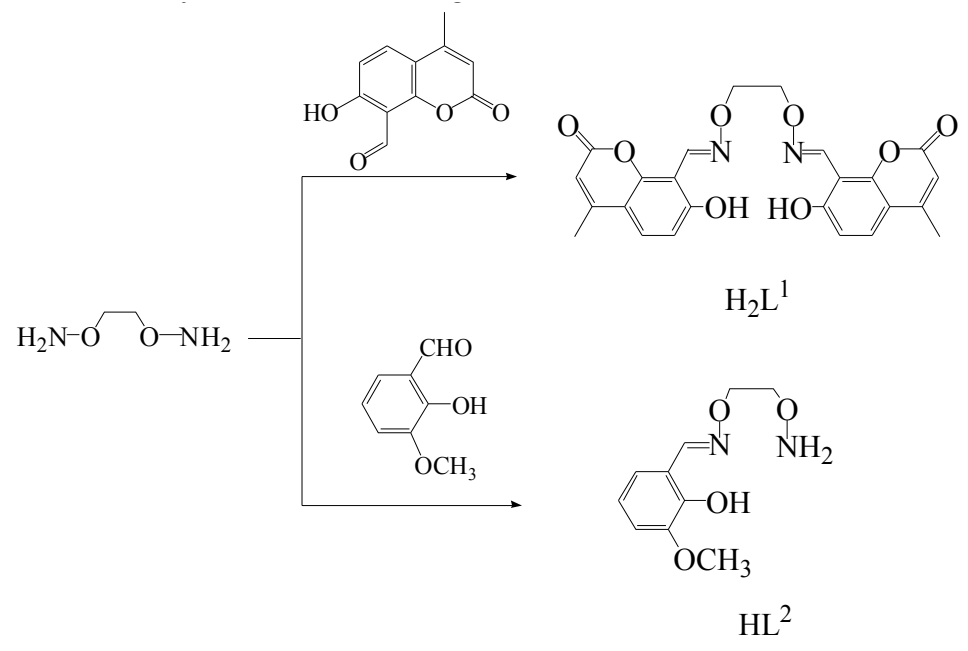

Scheme 1. Synthetic route to $\mathrm{H}_{2} \mathrm{~L}^{1}$ and $\mathrm{HL}^{2}$.

$\mathrm{H}_{2} \mathrm{~L}^{1}$ : A solution of 8-formyl-7-hydroxyl-4-methyl-coumarin (768.76 mg, $\left.2.9 \mathrm{mmol}\right)$ in methanol $(25 \mathrm{~mL})$ was added to a solution of 1,2-bis(aminooxy)ethane $(92.00 \mathrm{mg}, 1.0 \mathrm{mmol})$ in methanol $(25 \mathrm{~mL})$. The suspension solution was stirred and refluxed at $65^{\circ} \mathrm{C}$ for $4 \mathrm{~h}$, and then a yellowish solid of the salamo-type ligand $\left(\mathrm{H}_{2} \mathrm{~L}\right)$ was obtained, which was collected by suction filtration. Yield: $83.2 \%$, m.p. 287-288 ${ }^{\circ} \mathrm{C}$. Anal. Calcd for $\mathrm{C}_{24} \mathrm{H}_{20} \mathrm{~N}_{2} \mathrm{O}_{8}(\%): \mathrm{C}, 62.07 ; \mathrm{H}, 4.34 ; \mathrm{N}, 6.03$. Found: $\mathrm{C}, 61.84 ; \mathrm{H}, 4.41 ; \mathrm{N}$, 6.06. ${ }^{1} \mathrm{H}$ NMR $\left(400 \mathrm{MHz}, \mathrm{CDCl}_{3}\right), \delta 10.72(\mathrm{~s}, 2 \mathrm{H}), 8.95(\mathrm{~s}, 2 \mathrm{H}), 7.50(\mathrm{~d}, J=8.9 \mathrm{~Hz}, 2 \mathrm{H}), 6.93(\mathrm{~d}, J=8.9 \mathrm{~Hz}$, $2 \mathrm{H}), 6.14(\mathrm{~s}, 2 \mathrm{H}), 4.54(\mathrm{~s}, 4 \mathrm{H}), 2.40(\mathrm{~s}, 6 \mathrm{H})$.

\subsection{Synthesis of $H L^{2}$}

$\mathrm{HL}^{2}$ : An methanol solution $(25 \mathrm{~mL})$ of 3-methoxysalicylaldehyde $(1 \mathrm{mmol}, 152.6 \mathrm{mg})$ was added dropwisely to 1,2-bis(aminooxy)ethane $(1.5 \mathrm{mmol}, 138.0 \mathrm{mg})$ in methanol solution $(25 \mathrm{~mL})$. 
The resulting mixed solution was heated for $3 \mathrm{~h}$ between 55 and $60{ }^{\circ} \mathrm{C}$ temperature range. The solution was concentrated in vacuo and the residue was purified by column chromatography $\left(\mathrm{SiO}_{2}\right.$, chloroform/ethyl acetate, 30:1) to afford a colourless flocculent crystalline solid, then the half-salamo-type ligand $\left(\mathrm{HL}^{2}\right)$ was obtained, which was collected by suction filtration. Yield: $79.4 \%$. m.p. 91-92 ${ }^{\circ} \mathrm{C}$. Anal. Calc. for $\mathrm{C}_{10} \mathrm{H}_{14} \mathrm{~N}_{2} \mathrm{O}_{4}(\%)$ : C 53.09; H 6.24; N 12.38. Found: $\mathrm{C} 53.21 ; \mathrm{H} 6.19 ; \mathrm{N}$ 12.29. ${ }^{1} \mathrm{H}$ NMR $\left(400 \mathrm{MHz}, \mathrm{CDCl}_{3}\right), \delta 9.87(\mathrm{~s}, 1 \mathrm{H}), 8.22(\mathrm{~s}, 1 \mathrm{H}), 6.91(\mathrm{dd}, J=7.9,1.5 \mathrm{~Hz}, 1 \mathrm{H}), 6.86(\mathrm{~s}, 1 \mathrm{H})$, $6.80(\mathrm{dd}, J=7.7,1.7 \mathrm{~Hz}, 1 \mathrm{H}), 5.52(\mathrm{~s}, 2 \mathrm{H}), 4.40-4.33(\mathrm{~m}, 2 \mathrm{H}), 4.00-3.94(\mathrm{~m}, 2 \mathrm{H}), 3.91(\mathrm{~s}, 3 \mathrm{H})$.

\subsection{Synthesis of Complex 1}

To a ethanol solution ( $2 \mathrm{~mL}$ ) of zinc(II) acetate dehydrate $(0.01 \mathrm{mmol}, 2.19 \mathrm{mg})$, and a solution of $\mathrm{H}_{2} \mathrm{~L}^{1}$ (0.01 mmol, $4.64 \mathrm{mg}$ ) in $6 \mathrm{~mL}$ of dichloromethane was added dropwise, and immediately the mixed solution colour changed to yellow. The mixture solution was filtered and the filtrate was allowed to stand for two weeks. Through partial solvent evaporation, single crystals suitable for $\mathrm{X}$-ray diffraction analysis were obtained after two weeks. Yield: $48.2 \%$. Anal. Calcd for $\mathrm{C}_{26} \mathrm{H}_{24} \mathrm{~N}_{2} \mathrm{O}_{9} \mathrm{Zn}$ $\left(\left[\mathrm{Zn}\left(\mathrm{L}^{1}\right)(\mathrm{EtOH})\right](1)\right)(\%): \mathrm{C}, 54.42 ; \mathrm{H}, 4.22 ; \mathrm{N}, 4.88 ; \mathrm{Zn}, 11.39$. Found: C, 54.29; H, 4.29; N, 4.80; Zn, 11.25.

\subsection{Synthesis of Complex 2}

To a methanol solution ( $1 \mathrm{~mL}$ ) of zinc(II) acetate dehydrate $(0.03 \mathrm{mmol}, 6.57 \mathrm{mg})$, and a solution of $\mathrm{HL}^{2}(0.02 \mathrm{mmol}, 9.28 \mathrm{mg})$ in $2 \mathrm{~mL}$ of chloroform was added dropwise, The colour of the mixing solution turned to yellow immediately, then the mixture was filtered and the filtrate was obtained. The single crystals suitable for $\mathrm{X}$-ray diffraction studies were obtained by vapour diffusion of diethyl ether into the filtrate for two days at room temperature. Yield: 52.6\%. Anal. Calcd for $\mathrm{C}_{29} \mathrm{H}_{39} \mathrm{Cl}_{3} \mathrm{~N}_{4} \mathrm{O}_{16} \mathrm{Zn}_{3}$ $\left(\left[\left\{\mathrm{ZnL}^{2}(\mathrm{OAc})_{2}\right\}_{2} \mathrm{Zn}\right] \cdot \mathrm{CHCl}_{3}(2)\right)(\%): \mathrm{C}, 34.76 ; \mathrm{H}, 3.92 ; \mathrm{N}, 5.59 ; \mathrm{Zn}, 19.57$. Found: $\mathrm{C}, 34.55 ; \mathrm{H}, 3.98 ; \mathrm{N}$, 5.37; Zn, 19.26 .

\subsection{Crystal Structure Determinations of Complexes $\mathbf{1}$ and $\mathbf{2}$}

The crystal diffractometer provides a monochromatic beam of Mo K $\alpha$ radiation $(0.71073 \AA)$ produced using Graphite monochromator from a sealed Mo X-ray tube was used for obtaining crystal data for complexes 1 and 2 at 173.00(10) and 292.38(10), respectively. The LP factor semi-empirical absorption corrections were applied using the SADABS program. The structures were solved by the direct methods (SHELXS-2014) [48]. The H atoms were included at the calculated positions and constrained to ride on their parent atoms. All non-hydrogen atoms were refined anisotropically using a full-matrix least-squares procedure on $F^{2}$ with SHELXL-2014 [48]. The crystal data and experimental parameters relevant to the structure determinations are listed in Table 1.

Crystallographic data have been deposited with the Cambridge Crystallographic Data Centre as supplementary publication, No. CCDC 1564063 and 1564062 for complexes $\mathbf{1}$ and 2. Copies of the data can be obtained free of charge on application to CCDC, 12 Union Road, Cambridge CB21EZ, UK (Telephone: (44) 01223 762910; Fax: +44-1223-336033; E-mail: deposit @ccdc.cam.ac.uk). These data can be also obtained free of charge at www.ccdc.cam.Ac.uk/conts/retrieving.html.

Table 1. Crystal data and structure refinement parameters for complexes $\mathbf{1}$ and $\mathbf{2 .}$

\begin{tabular}{ccc}
\hline Complex & $\mathbf{1}$ & $\mathbf{2}$ \\
\hline Formula & $\mathrm{C}_{26} \mathrm{H}_{24} \mathrm{~N}_{2} \mathrm{O}_{9} \mathrm{Zn}$ & $\mathrm{C}_{29} \mathrm{H}_{39} \mathrm{Cl}_{3} \mathrm{~N}_{4} \mathrm{O}_{16} \mathrm{Zn}_{3}$ \\
Formula weight & 573.84 & 1002.16 \\
Temperature $(\mathrm{K})$ & $173.00(10)$ & $292.38(10)$ \\
Wavelength $(\AA)$ & 0.71073 & 0.71073 \\
Crystal system & Monoclinic & Triclinic \\
Space group & $P 21 / n$ & $P-1$ \\
\hline
\end{tabular}


Table 1. Cont.

\begin{tabular}{|c|c|c|}
\hline Complex & 1 & 2 \\
\hline \multicolumn{3}{|l|}{ Unit cell dimensions } \\
\hline$a(\AA)$ & $12.811(3)$ & 13.1694(13) \\
\hline$b(\AA)$ & $13.4725(9)$ & $13.3568(13)$ \\
\hline$c(\AA)$ & $15.393(3)$ & $16.1452(14)$ \\
\hline$\alpha\left({ }^{\circ}\right)$ & 90 & $94.664(8)$ \\
\hline$\beta\left({ }^{\circ}\right)$ & 107.665(19) & $113.074(10)$ \\
\hline$\gamma\left({ }^{\circ}\right)$ & 90 & $112.722(9)$ \\
\hline$V\left(\AA^{3}\right)$ & $2531.6(8)$ & $2317.6(4)$ \\
\hline Z & 4 & 2 \\
\hline$D_{c}\left(\mathrm{~g} \mathrm{~cm}^{-3}\right)$ & 1.506 & 1.430 \\
\hline$\mu\left(\mathrm{mm}^{-1}\right)$ & 1.028 & 1.775 \\
\hline$F(000)$ & 1184 & 1012 \\
\hline Crystal size (mm) & $0.24 \times 0.19 \times 0.17$ & $0.22 \times 0.18 \times 0.14$ \\
\hline$\theta$ Range $\left(^{\circ}\right)$ & $3.338-25.008$ & $3.34-26.02$ \\
\hline Index ranges & $\begin{array}{c}-13 \leq \mathrm{h} \leq 15 \\
-16 \leq \mathrm{k} \leq 14 \\
-14 \leq 1 \leq 18\end{array}$ & $\begin{array}{l}-10 \leq \mathrm{h} \leq 16 \\
-16 \leq \mathrm{k} \leq 16 \\
-19 \leq 1 \leq 15\end{array}$ \\
\hline Reflections collected & 8334 & $1 \overline{6}, 91 \overline{2}$ \\
\hline Independent reflections & 4446 & 9102 \\
\hline$R_{\text {int }}$ & 0.0996 & 0.0522 \\
\hline Completeness & $99.6 \%$ & $99.79 \%$ \\
\hline Data/restraints/parameters & $4446 / 16 / 349$ & $9102 / 1 / 502$ \\
\hline GOF & 1.001 & 0.963 \\
\hline Final $R_{1}, w R_{2}$ indices & $0.0581 / 0.0934$ & $0.0633 / 0.1473$ \\
\hline$R_{1}, w R_{2}$ indices (all data) & $0.0721 / 0.1598$ & $0.1236 / 0.1774$ \\
\hline Largest differences & $\begin{array}{c}0.926 /-0.772 \\
\text { peak and hole }\left(\mathrm{e} \AA^{-3}\right)\end{array}$ & $0.873 /-0.587$ \\
\hline
\end{tabular}

\section{Results and Discussion}

Complexes 1 and 2 constructed from salamo and half-salamo chelating ligands $\left(\mathrm{H}_{2} \mathrm{~L}^{1}\right.$ and $\left.\mathrm{HL}^{2}\right)$ have been synthesized, and characterized by IR spectra, UV-VIS spectra, and X-ray crystallography analyses. The fluorescence titration experiments were used to characterize fluorescence properties of complexes $\mathbf{1}$ and $\mathbf{2}$. The normalized fluorescent spectra exhibits that complexes $\mathbf{1}$ and $\mathbf{2}$ have favourable fluorescent emissions in different solvents.

\subsection{IR Spectra}

The FT-IR spectra of $\mathrm{H}_{2} \mathrm{~L}^{1}$ and $\mathrm{HL}^{2}$ with their corresponding complexes $\mathbf{1}$ and $\mathbf{2}$ exhibit various bands in the $4000-400 \mathrm{~cm}^{-1}$ region (Figure 1). A typical $\mathrm{C}=\mathrm{N}$ stretching band of the free ligands $\mathrm{H}_{2} \mathrm{~L}^{1}$ and $\mathrm{HL}^{2}$ appears at 1619 and $1604 \mathrm{~cm}^{-1}$, and that of complexes $\mathbf{1}$ and 2 at 1581 and $1597 \mathrm{~cm}^{-1}$, respectively [49]. The $\mathrm{C}=\mathrm{N}$ stretching frequencies are shifted to low frequencies, indicating that the $\mathrm{Zn}(\mathrm{II})$ atoms are coordinated by azomethine nitrogen atoms of $\left(\mathrm{L}^{1}\right)^{2-}$ and $\left(\mathrm{L}^{2}\right)^{1-}$ moieties. Therefore, the conclusion could be made that $\mathrm{H}_{2} \mathrm{~L}^{1}$ and $\mathrm{HL}^{2}$ coordinated with $\mathrm{Zn}(\mathrm{II})$ atoms [50]. The typical $\mathrm{C}=\mathrm{O}$ stretching band at $1728 \mathrm{~cm}^{-1}$ was exhibited by the free ligands $\mathrm{H}_{2} \mathrm{~L}^{1}$, where at $1712 \mathrm{~cm}^{-1}$ show the $\mathrm{C}=\mathrm{O}$ stretching band in complex 1 . The free ligands $\mathrm{H}_{2} \mathrm{~L}^{1}$ and $\mathrm{HL}^{2}$ exhibit $\mathrm{Ar}-\mathrm{O}$ stretching frequencies at 1288 and $1249 \mathrm{~cm}^{-1}$, while the Ar-O stretching frequencies of the complexes $\mathbf{1}$ and $\mathbf{2}$ appear at 1226 and $1242 \mathrm{~cm}^{-1}$, respectively. The Ar-O stretching frequencies are shifted to low frequencies, which could be evidence of the $\mathrm{Zn}-\mathrm{O}$ bond formation between $\mathrm{Zn}$ (II) atoms and oxygen atoms of phenolic groups [51].

The far-IR spectra (550-100 $\mathrm{cm}^{-1}$ ) of both complexes $\mathbf{1}$ and $\mathbf{2}$ were also obtained so as to identify the bonds of $\mathrm{Zn}-\mathrm{O}$ and $\mathrm{Zn}-\mathrm{N}$ frequencies. The bands at 447 and $463 \mathrm{~cm}^{-1}$ of complexes 1 and 2 can be attributed to $v_{(\mathrm{Zn}-\mathrm{O})}$, while the bands at 516 and $564 \mathrm{~cm}^{-1}$ are assigned to $v_{(\mathrm{Zn}-\mathrm{N})}$ [52]. 


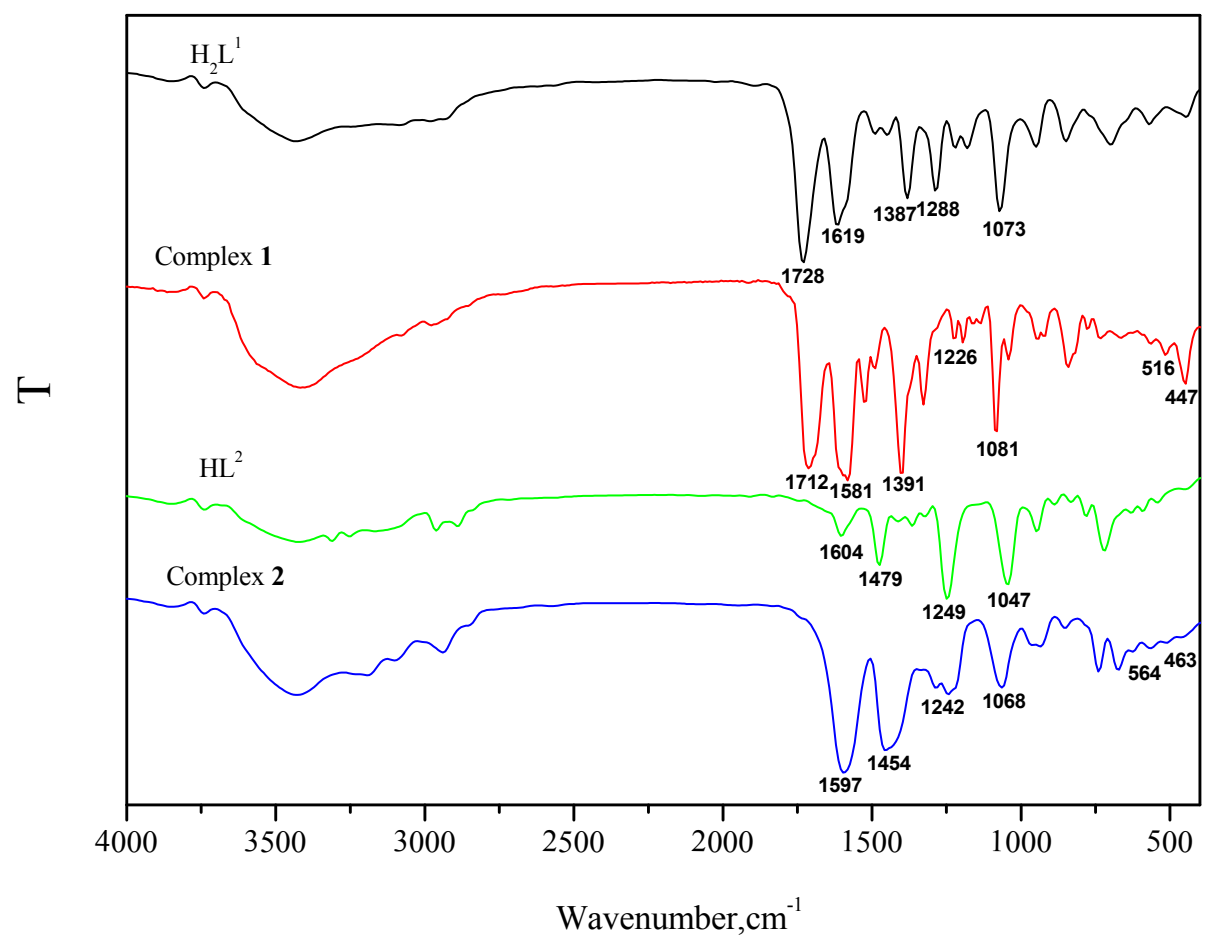

Figure 1. The FT-IR spectra of the ligands and their complexes 1 and $2\left(\mathrm{~cm}^{-1)}\right.$.

\subsection{Crystal Structure of Complex 1}

As depicted in Figure 2 and Table 2, complex 1 crystallizes in the monoclinic space group $P 2_{1} / n$, which consists of one $\mathrm{Zn}$ (II) ion, one completely deprotonated $\left(\mathrm{L}^{1}\right)^{2-}$ unit, and one coordinated ethanol molecule. The $\mathrm{Zn}$ (II) ion is penta-coordinated by two oxime nitrogen (N1 and N2) atoms and two phenoxo oxygen (O3 and $\mathrm{O} 6)$ atoms, the four atoms are all from one deprotonated $(\mathrm{L})^{2-}$ unit, and one oxygen (O9) atom from the coordinated ethanol molecule (Figure 2a). The coordination environment around the $\mathrm{Zn}$ (II) ion is best described as a slightly distorted trigonal bipyramidal geometry, which obtains the geometry adopted by the $\mathrm{Zn}(\mathrm{II})$ ion, and the $\tau$ value was estimated to be $\tau=0.845$ (Figure $2 b$ ) $[53,54]$. The phenolic oxygen (O3) and the oxime nitrogen (N2) of the $\left(\mathrm{L}^{1}\right)^{2-}$ unit and one oxygen (O9) atom of the coordinated ethanol molecule constitute, together, the basal plane

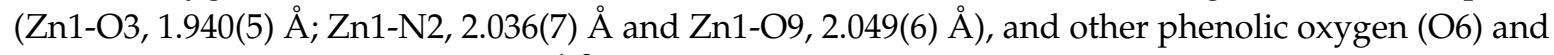
oxime nitrogen $(\mathrm{N} 1)$ atoms of the $\left(\mathrm{L}^{1}\right)^{2-}$ unit occupy the axial positions (Zn1-O6, 1.994(5) and Zn1-N1, 2.187(7) $\AA$ ). The three coordination atoms on the base plane and the $\mathrm{Zn}(\mathrm{II})$ ion is $0.062(3) \AA$ displaced from the mean plane $[55,56]$. Additionally, four of the intramolecular $\mathrm{C} 10-\mathrm{H} 10 \cdots \mathrm{O} 2, \mathrm{C} 11-\mathrm{H} 11 \mathrm{~A} \cdots \mathrm{O} 9$,

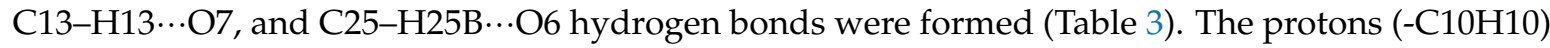
and $(-\mathrm{C} 13 \mathrm{H} 13)$ of $\left(\mathrm{L}^{1}\right)^{2-}$ unit are hydrogen bonded to two of ester oxygen $(\mathrm{O} 2$ and $\mathrm{O} 7)$ atoms of $\left(\mathrm{L}^{1}\right)^{2-}$ units, respectively, and the proton $(-\mathrm{C} 11 \mathrm{H} 11 \mathrm{~A})$ of the $\left(\mathrm{L}^{1}\right)^{2-}$ unit is hydrogen bonded to one oxygen (O9) atom of the coordinated ethanol molecule. Meanwhile, the proton (-C25H25B) of the coordinated ethanol molecule is hydrogen bonded to one phenoxo oxygen $(\mathrm{O} 6)$ atom of the $\left(\mathrm{L}^{1}\right)^{2-}$ unit. The formation of intramolecular hydrogen bonds may result in a relatively stable chemical property of complex $\mathbf{1}[57,58]$. 
(a)

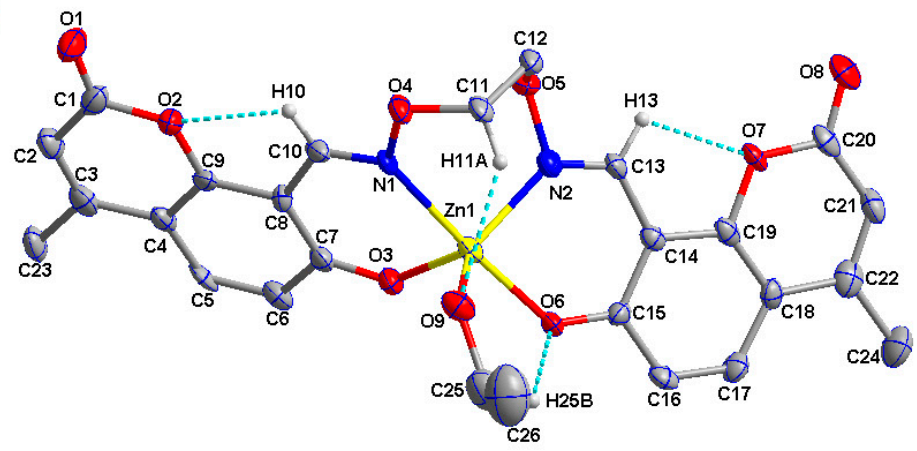

(b)

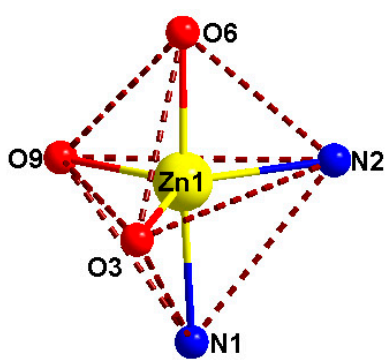

Figure 2. (a) Molecular structure and atom numberings of complex 1 with 30\% probability displacement ellipsoids (hydrogen atoms are omitted for clarity). (b) Coordination polyhedron for $\mathrm{Zn}$ (II) ion of complex 1.

Table 2. Selected bond lengths $(\AA)$ and angles $\left(^{\circ}\right)$ for complex $\mathbf{1}$.

\begin{tabular}{cccc}
\hline Bond & & & \\
\hline Zn1-O3 & $1.940(5)$ & Zn1-N1 & $2.187(7)$ \\
Zn1-O6 & $1.994(5)$ & Zn1-N2 & $2.036(7)$ \\
Zn1-O9 & $2.049(6)$ & & \\
Angles & & & \\
O3-Zn1-O6 & $97.1(2)$ & O3-Zn1-O9 & $111.5(2)$ \\
O3-Zn1-N1 & $86.7(2)$ & O3-Zn1-N2 & $125.1(3)$ \\
O6-Zn1-O9 & $91.7(2)$ & O6-Zn1-N1 & $175.8(2)$ \\
O6-Zn1-N2 & $87.0(2)$ & N1-Zn1-O9 & $88.5(3)$ \\
N2-Zn1-O9 & $123.2(3)$ & N2-Zn1-N1 & $89.4(3)$ \\
\hline
\end{tabular}

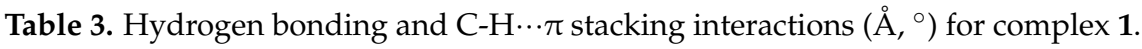

\begin{tabular}{|c|c|c|c|c|}
\hline $\mathrm{D}-\mathrm{H} \cdots \mathrm{A}$ & D-H & $\mathbf{H} \cdots \mathbf{A}$ & D..A & D-H $\cdots A$ \\
\hline $\mathrm{C} 10-\mathrm{H} 10 \cdots \mathrm{O} 2$ & 0.93 & 2.30 & $2.670(11)$ & 103 \\
\hline C11-H11A‥O9 & 0.97 & 2.59 & $3.421(10)$ & 143 \\
\hline 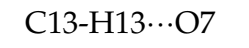 & 0.93 & 2.25 & $2.636(10)$ & 104 \\
\hline C25-H25B …6 & 0.97 & 2.46 & $3.055(14)$ & 119 \\
\hline C2-H2 ‥O4 & 0.93 & 2.58 & $3.454(12)$ & 158 \\
\hline C11-H11B ‥ & 0.97 & 2.49 & $3.281(9)$ & 139 \\
\hline C12-H12A $\cdots \mathrm{O} 1$ & 0.97 & 2.51 & $3.424(12)$ & 157 \\
\hline $\mathrm{C} 12-\mathrm{H} 12 \mathrm{~B} \cdots \mathrm{O} 3$ & 0.97 & 2.56 & $3.494(11)$ & 161 \\
\hline $\mathrm{C} 21-\mathrm{H} 21 \cdots \mathrm{O} 3$ & 0.93 & 2.54 & $3.277(11)$ & 137 \\
\hline O9-H9...O8 & 0.86 & 1.99 & $2.725(10)$ & 144 \\
\hline C26-H26B $\cdots \mathrm{Cg} 3$ & 0.96 & 2.99 & $3.398(17)$ & 107 \\
\hline
\end{tabular}

Note: $\mathrm{Cg} 3=\mathrm{O}_{2}-\mathrm{C}_{1}-\mathrm{C}_{2}-\mathrm{C}_{3}-\mathrm{C}_{4}-\mathrm{C}_{9}$.

As shown in Figure 3 and Table 3, six pairs of intermolecular hydrogen bonds, O9-H9...O 8 , $\mathrm{C} 2-\mathrm{H} 2 \cdots \mathrm{O} 4, \mathrm{C} 11-\mathrm{H} 11 \mathrm{~B} \cdots \mathrm{O} 8, \mathrm{C} 12-\mathrm{H} 12 \mathrm{~A} \cdots \mathrm{O} 1, \mathrm{C} 12-\mathrm{H} 12 \mathrm{~B} \cdots \mathrm{O} 3$, and $\mathrm{C} 21-\mathrm{H} 21 \cdots \mathrm{O} 3$ are formed. In addition, the $\mathrm{Cg} 3\left(\mathrm{O}_{2}-\mathrm{C}_{1}-\mathrm{C}_{2}-\mathrm{C}_{3}-\mathrm{C}_{4}-\mathrm{C}_{9}\right)$ of pyrone rings as acceptors forms one hydrogen bond with the protons (-C26H26B) of coordinated ethanol molecules. The space skeleton of complex 1 adopts a 3D supramolecular structure by the action of hydrogen bond and $\mathrm{C}-\mathrm{H} \cdots \pi$ stacking interactions $[34,59,60]$. 


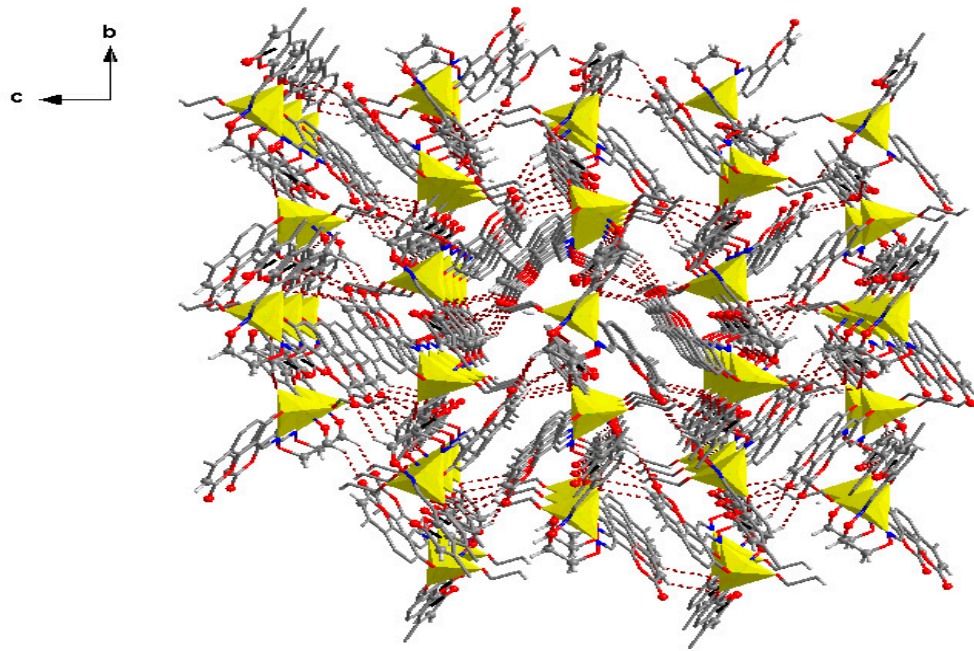

Figure 3. View of the 3D supramolecular structure of complex 1 showing the $\mathrm{O}-\mathrm{H} \cdots \mathrm{O}, \mathrm{C}-\mathrm{H} \cdots \mathrm{O}$, hydrogen bonds, and $\mathrm{C}-\mathrm{H} \cdots \pi$ stacking interactions.

\subsection{Crystal Structure of Complex 2}

X-ray crystallographic analysis of complex 2 reveals an asymmetric trinuclear structure. It crystallizes in the triclinic system, space group P-1, consists of three $\mathrm{Zn}$ (II) ions, two completely deprotonated $\left(L^{2}\right)^{1-}$ units, four coordinated acetate ions. Selected bond lengths and angles are listed in Table 4.

Table 4. Selected bond lengths $(\AA)$ and angles $\left(^{\circ}\right)$ for complex 2.

\begin{tabular}{cccc}
\hline Bond & & & \\
\hline Zn1-O2 & $2.017(4)$ & Zn1-O9 & $2.203(4)$ \\
Zn1-O10 & $2.191(5)$ & Zn1-O11 & $2.112(4)$ \\
Zn1-N1 & $2.218(5)$ & Zn1-N2 & $2.077(5)$ \\
Zn2-O1 & $2.269(4)$ & Zn2-O2 & $2.006(4)$ \\
Zn2-O5 & $2.336(4)$ & Zn2-O6 & $2.001(4)$ \\
Zn2-O12 & $2.032(4)$ & Zn2-O13 & $2.022(4)$ \\
Zn3-O6 & $2.006(4)$ & Zn3-O14 & $2.147(4)$ \\
Zn3-O15 & $2.209(5)$ & Zn3-O16 & $2.160(5)$ \\
Zn3-N3 & $2.206(5)$ & Zn3-N4 & $2.085(5)$ \\
Angles & & & \\
O2-Zn1-O9 & $155.36(16)$ & O2-Zn1-O10 & $96.75(16)$ \\
O2-Zn1-O11 & $95.76(15)$ & O2-Zn1-N1 & $81.53(17)$ \\
O2-Zn1-N2 & $99.03(17)$ & O9-Zn1-N1 & $94.48(18)$ \\
O10-Zn1-O9 & $59.04(16)$ & O10-Zn1-N1 & $93.23(19)$ \\
O11-Zn1-O9 & $89.09(16)$ & O11-Zn1-O10 & $89.72(18)$ \\
O11-Zn1-N1 & $176.21(18)$ & N2-Zn1-O9 & $105.28(18)$ \\
N2-Zn1-O10 & $164.21(18)$ & N2-Zn1-O11 & $88.08(17)$ \\
N2-Zn1-N1 & $89.72(18)$ & O1-Zn2-O5 & $84.12(15)$ \\
O2-Zn2-O1 & $74.99(15)$ & O2-Zn2-O5 & $85.59(16)$ \\
O2-Zn2-O12 & $97.76(16)$ & O2-Zn2-O13 & $100.51(15)$ \\
O6-Zn2-O1 & $84.90(16)$ & O6-Zn2-O2 & $152.58(15)$ \\
O6-Zn2-O5 & $73.79(16)$ & O6-Zn2-O12 & $101.12(15)$ \\
O6-Zn2-O13 & $96.80(16)$ & O12-Zn2-O1 & $91.08(15)$ \\
O12-Zn2-O5 & $173.26(15)$ & O13-Zn2-O1 & $171.40(15)$ \\
O13-Zn2-O5 & $88.25(16)$ & O13-Zn2-O12 & $96.84(15)$ \\
O6-Zn3-O14 & $92.82(15)$ & O6-Zn3-O15 & $95.64(16)$ \\
O6-Zn3-O16 & $155.32(16)$ & O6-Zn3-N3 & $82.60(17)$ \\
O6-Zn3-N4 & $99.71(18)$ & O14-Zn3-O15 & $88.68(17)$ \\
O14-Zn3-O16 & $88.30(16)$ & O14-Zn3-N3 & $174.96(19)$ \\
O16-Zn3-O15 & $59.72(16)$ & O16-Zn3-N3 & $96.74(19)$ \\
N3-Zn3-O15 & $93.87(19)$ & N4-Zn3-O14 & $88.59(17)$ \\
N4-Zn3-O15 & $164.52(19)$ & N4-Zn3-O16 & $104.96(18)$ \\
N4-Zn3-N3 & $90.08(19)$ & & \\
\hline & & & \\
\hline & & & \\
\hline
\end{tabular}


As shown in Figure 4, the two terminal $\mathrm{Zn}$ (II) ions ( $\mathrm{Zn} 1$ and $\mathrm{Zn} 3$ ) were both located in the cis- $\mathrm{N}_{2} \mathrm{O}$ coordination cavity of the deprotonated $\left(\mathrm{L}^{2}\right)^{1-}$ units, the carboxylate oxygen (O9 and O10) and (O15 and $\mathrm{O} 16)$ atoms from coordinated acetate ions chelate to $\mathrm{Zn} 1$ and $\mathrm{Zn} 3$, and carboxylate oxygen (O11 and O14) atoms from the $\mu_{2}$-acetate bridge to $\mathrm{Zn} 1$ and $\mathrm{Zn} 3$ in axial positions (Figure 4a). The dihedral angle between the coordination planes of O10-Zn1-O2 and N2-Zn1-O9 is 4.18(2), the dihedral angle between the coordination planes of N4-Zn3-O16 and N6-Zn3-O15 is 2.12(2), indicating slight distortion octahedral geometry from the square planar structure. Then, the coordination sphere of the central $\mathrm{Zn}$ (II) ( $\mathrm{Zn} 2$ ) atom is completed by double $\mu_{2}$-phenoxo oxygen (O2 and $\mathrm{O} 6$ ) atoms from two $\left(\mathrm{L}^{2}\right)^{1-}$ moieties, two $\mu_{2}$-acetato oxygen (O12 and $\left.\mathrm{O} 13\right)$ atoms and two oxygen $(\mathrm{O} 5$ and $\mathrm{O} 1)$ atoms from methoxyl groups. As a result the central $\mathrm{Zn} 2$ atom finally has an $\mathrm{O}_{2} \mathrm{O}_{2} \mathrm{O}_{2}$ coordination environment. Then, all of the hexa-coordinated $\mathrm{Zn}$ (II) ions of complex 2 have slightly distorted octahedral symmetries (Figure $4 b$ ) [61,62].

(a)

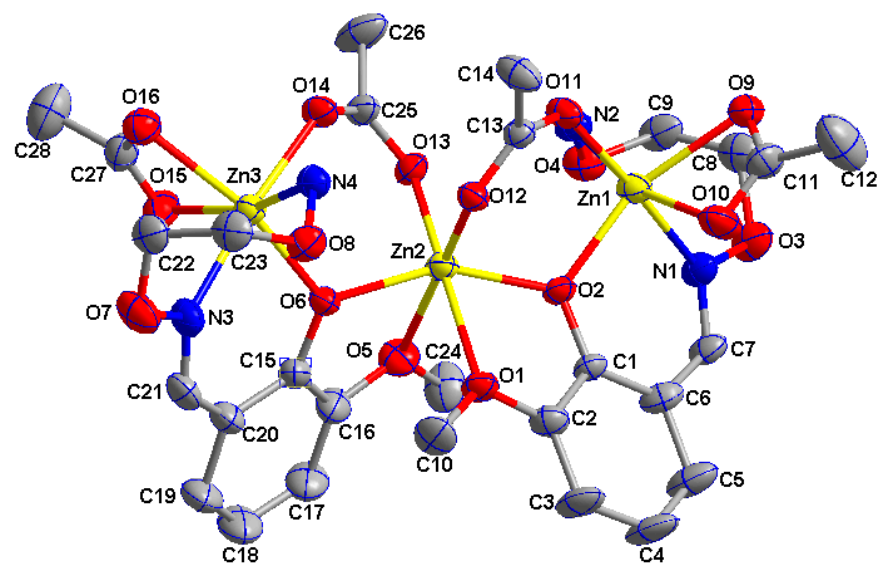

(b)
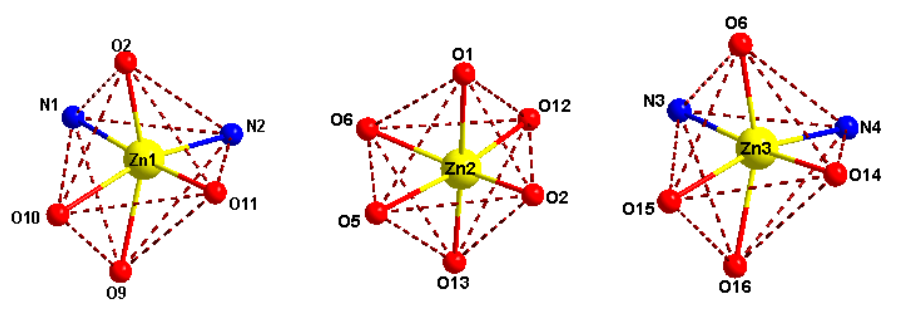

Figure 4. (a) Molecular structure and atom numberings of complex 2 with $30 \%$ probability displacement ellipsoids (hydrogen atoms are omitted for clarity). (b) Coordination polyhedra for Zn1, Zn2, and Zn3 ions of complex 2 .

As depicted in Figure 5, in complex 2, four pairs of intramolecular hydrogen bonds N2-H2A $\cdots \mathrm{O} 13$, $\mathrm{N} 4-\mathrm{H} 4 \mathrm{~A} \cdots \mathrm{O} 12, \mathrm{C} 8-\mathrm{H} 8 \mathrm{~B} \cdots \mathrm{O} 9$ and $\mathrm{C} 22-\mathrm{H} 22 \mathrm{~B} \cdots \mathrm{O} 16$ are formed. The protons (-N2H2A and -N4H4A) of $\left(\mathrm{L}^{2}\right)^{1-}$ units form hydrogen bonds with two oxygen (O13 and $\left.\mathrm{O} 12\right)$ atoms of $\mu_{2}$-acetate ions, respectively. The protons (-C8H8B and -C22H22B) from ethylenedioxime carbon atoms of $\left(\mathrm{L}^{2}\right)^{1-}$ units form hydrogen bonds with carboxylate oxygen (O9 and $\mathrm{O} 16)$ atoms of coordinated acetate ions [63].

As illustrated in Figure 6 and Table 5, a large number of intermolecular hydrogen bonds and $\mathrm{C}-\mathrm{Cl} \cdots \pi, \mathrm{C}-\mathrm{H} \cdots \pi$ stacking interactions in complex 2 . The $2 \mathrm{D}$ supramolecular structure of complex 2 is

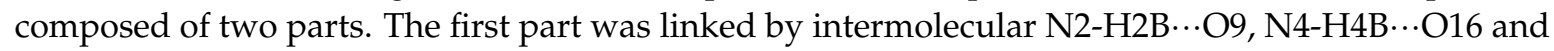
$\mathrm{C} 29-\mathrm{H} 29 \cdots \mathrm{O} 15[41,64]$ hydrogen bonding interactions. The other part was made up of the C-Cl $\cdots \pi[27]$, $\mathrm{C}-\mathrm{H} \cdots \pi$ stacking interactions. The $\mathrm{Cg} 7\left(\mathrm{C}_{15}-\mathrm{C}_{20}\right)$ and $\mathrm{Cg} 6\left(\mathrm{C}_{1}-\mathrm{C}_{6}\right)$ of phenyl rings as acceptors form two hydrogen bonds with the protons $(-\mathrm{C} 29 \mathrm{Cl} 2$ and $-\mathrm{C} 10 \mathrm{H} 10 \mathrm{~B})$ of adjacent molecules. The intermolecular hydrogen bonds and $\mathrm{C}-\mathrm{Cl} \cdots \pi, \mathrm{C}-\mathrm{H} \cdots \pi$ stacking interactions of complex 2 not only make its spatial structure more diversified, but also may cause better chemical stability $[27,59]$. 


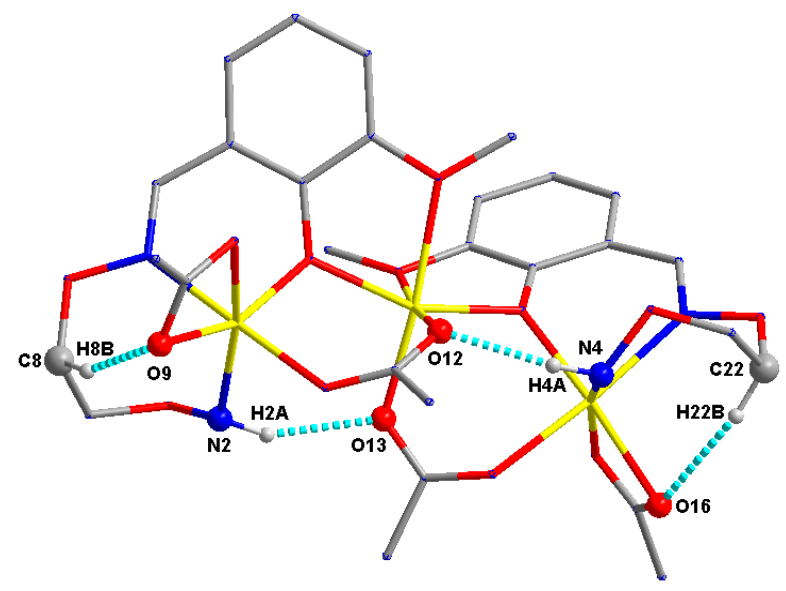

Figure 5. Intramolecular $\mathrm{C}-\mathrm{H} \cdots \mathrm{O}$ and $\mathrm{N}-\mathrm{H} \cdots \mathrm{O}$ hydrogen bonds of complex 2 (hydrogen atoms, except those forming hydrogen bonds, are omitted for clarity).

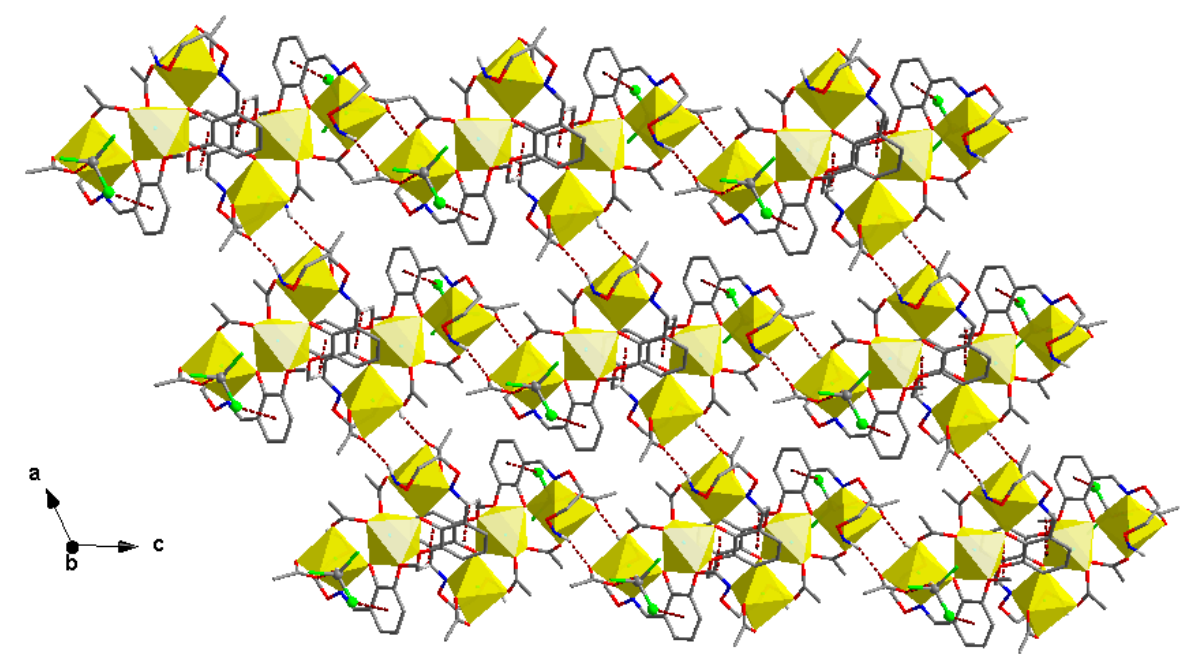

Figure 6. View of the 2D supramolecular structure of complex 2 showing the $\mathrm{N}-\mathrm{H} \cdots \mathrm{O}, \mathrm{C}-\mathrm{H} \cdots \mathrm{O}$ hydrogen bonding, and $\mathrm{C}-\mathrm{Cl} \cdots \pi, \mathrm{C}-\mathrm{H} \cdots \pi$ stacking interactions.

Table 5. Hydrogen bonding and $\mathrm{C}-\mathrm{H} \cdots \pi$ and $\mathrm{C}-\mathrm{Cl} \cdots \pi$ interactions $\left(\AA{ }^{\circ}{ }^{\circ}\right)$ for complex 2.

\begin{tabular}{|c|c|c|c|c|}
\hline $\mathrm{D}-\mathrm{H} \cdots \mathrm{A}$ & D-H & $\mathbf{H} \cdots \mathbf{A}$ & D..A & D-H $\cdots A$ \\
\hline $\mathrm{N} 2-\mathrm{H} 2 \mathrm{~A} \cdots \mathrm{O} 13$ & 0.90 & 2.06 & $2.890(7)$ & 153 \\
\hline N4-H4A …012 & 0.90 & 2.10 & $2.945(8)$ & 155 \\
\hline 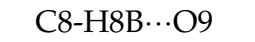 & 0.90 & 2.03 & $2.860(7)$ & 154 \\
\hline C22-H22B $\cdots$ O16 & 0.90 & 2.13 & $2.965(8)$ & 153 \\
\hline N2-H2B ‥O9 & 0.97 & 2.33 & $3.253(9)$ & 158 \\
\hline N4-H4B …O16 & 0.97 & 2.38 & $3.300(8)$ & 157 \\
\hline $\mathrm{C} 29-\mathrm{H} 29 \ldots \mathrm{O} 15$ & 0.98 & 2.35 & $3.19(2)$ & 145 \\
\hline N2-H2A $\cdots \mathrm{O} 13$ & 0.90 & 2.06 & $2.890(7)$ & 153 \\
\hline $\mathrm{C} 29-\mathrm{Cl} 2 \cdots \mathrm{Cg} 7$ & 1.687 & 3.979 & $4.652(18)$ & 102.7 \\
\hline C10-H10B …Cg6 & 0.96 & 2.69 & $3.481(9)$ & 140 \\
\hline
\end{tabular}

Note: $\mathrm{Cg} 7=\mathrm{C}_{15}-\mathrm{C}_{20} ; \mathrm{Cg} 6=\mathrm{C}_{1}-\mathrm{C}_{6}$.

\subsection{UV-VIS Spectra}

The UV-VIS absorption spectra of the free ligands $\mathrm{H}_{2} \mathrm{~L}^{1}$ and $\mathrm{HL}^{2}$ with their corresponding complexes $\mathbf{1}$ and 2 in the dichloromethane solutions $\left(1.0 \times 10^{-5} \mathrm{~mol} / \mathrm{L}\right)$ at $298 \mathrm{~K}$ are shown in Table 6 and Figure 7 . 
Table 6. Absorption maxima and molar extinction coefficients for complexes $\mathbf{1}$ and 2.

\begin{tabular}{ccccc}
\hline Compound & $\mathbf{c}$ & $\mathbf{A}(\varepsilon)$ & $\mathbf{B}(\varepsilon)$ & $\mathbf{C}(\varepsilon)$ \\
\hline $\mathrm{H}_{2} \mathrm{~L}^{1}$ & $1.0 \times 10^{-5}$ & $291\left(5.7 \times 10^{-4}\right)$ & $329\left(3.7 \times 10^{-4}\right)$ & $345\left(3.0 \times 10^{-4}\right)$ \\
Complex 1 & $1.0 \times 10^{-5}$ & $252\left(2.4 \times 10^{-4}\right)$ & $304\left(2.8 \times 10^{-4}\right)$ & $344\left(3.9 \times 10^{-4}\right)$ \\
HL $^{2}$ & $1.0 \times 10^{-5}$ & $270\left(4.6 \times 10^{-4}\right)$ & $322\left(0.8 \times 10^{-4}\right)$ & \\
Complex 2 & $1.0 \times 10^{-5}$ & $271\left(3.3 \times 10^{-4}\right)$ & $325\left(0.6 \times 10^{-4}\right)$ & \\
\hline
\end{tabular}

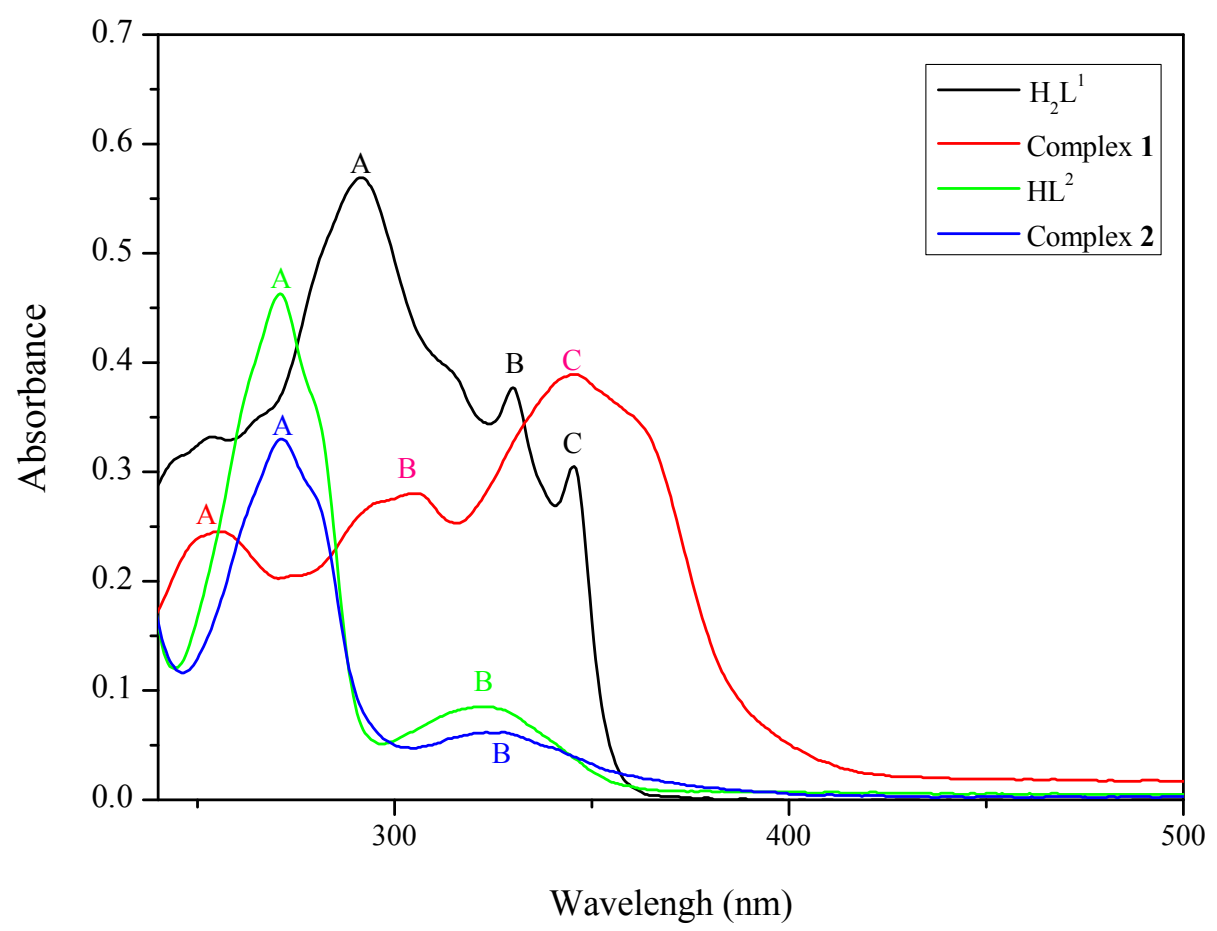

Figure 7. The UV-VIS spectra of the free ligands $\mathrm{H}_{2} \mathrm{~L}^{1}$ and $\mathrm{HL}^{2}$ with their corresponding complexes 1 and $2\left(\mathrm{~cm}^{-1}\right)$.

Obviously, the absorption peaks of the ligand $\mathrm{H}_{2} \mathrm{~L}^{1}$ and $\mathrm{HL}^{2}$ differ from those of their corresponding complexes $\mathbf{1}$ and $\mathbf{2}$. The absorption spectrum of the free salamo-type ligand $\mathrm{H}_{2} \mathrm{~L}^{1}$ consists of three relatively intense bands centered at 291,329 and $345 \mathrm{~nm}$, which may be assigned to the $\pi-\pi^{*}$ transitions of the phenyl rings of coumarin and the oxime group $[44,65]$. Upon coordination of the ligand, the absorption intensities are weakened compared with the free ligand $\mathrm{H}_{2} \mathrm{~L}^{1}$, which indicate that the oxime nitrogen atoms are involved in coordination to the $\mathrm{Zn}(\mathrm{II})$ atoms. Likewise, the absorption spectrum of the half-salamo ligand $\mathrm{HL}^{2}$ consists of two relatively intense bands centred at 271 and $323 \mathrm{~nm}$, which may be assigned to the $\pi-\pi^{*}$ transitions of the phenyl rings and the oxime group [45,65]. On the other hand, because of complex 2 is synthesized by the half-salamo ligand $\mathrm{HL}^{2}$, when the $\mathrm{Zn}$ (II) atoms coordinated to $\mathrm{HL}^{2}$, the conjugate system of complex $\mathbf{2}$ not change greatly compared with complex $\mathbf{1}$, which leads to the absorption spectra were almost unchanged before and after the complexation. Upon coordination of the ligand $\mathrm{HL}^{2}$, the absorption intensities are weakened compared with the free ligand $\mathrm{HL}^{2}$, which indicate that the oxime nitrogen atoms are involved in coordination with the $\mathrm{Zn}$ (II) atoms $[37,66]$.

\subsection{Fluorescence Properties}

The fluorescence titration experiments of $\mathrm{H}_{2} \mathrm{~L}^{1}$ and $\mathrm{HL}^{2}$ were determined in DMF solution $\left(2.0 \times 10^{-5} \mathrm{~mol} \cdot \mathrm{L}^{-1}\right)$ with $\mathrm{Zn}(\mathrm{OAc})_{2} \cdot 2 \mathrm{H}_{2} \mathrm{O}$ in methanol solution $\left(1 \times 10^{-3} \mathrm{~mol} \cdot \mathrm{L}^{-1}\right)$ are shown in Figures 8 and 9 . 


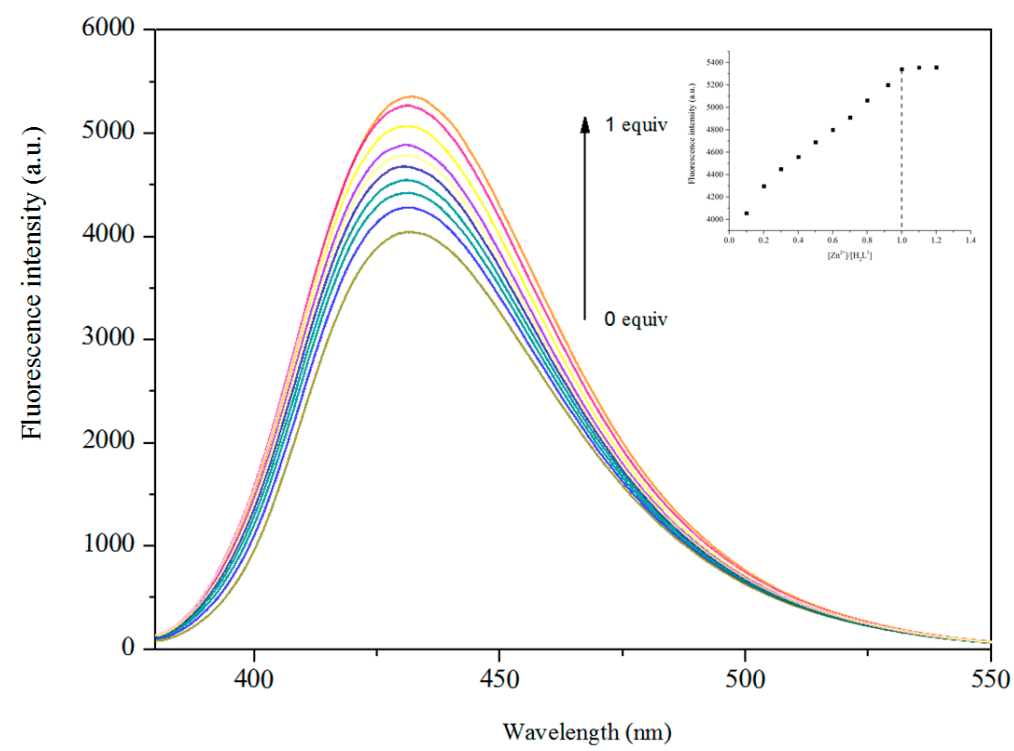

Figure 8. Absorption spectra of $\mathrm{H}_{2} \mathrm{~L}^{1}$ in DMF solution upon the addition of $\mathrm{Zn}^{2+}$. Inset: The absorbance at $432 \mathrm{~nm}$ varied as an interaction of $\left[\mathrm{Zn}^{2+}\right] /\left[\mathrm{H}_{2} \mathrm{~L}^{1}\right]$.

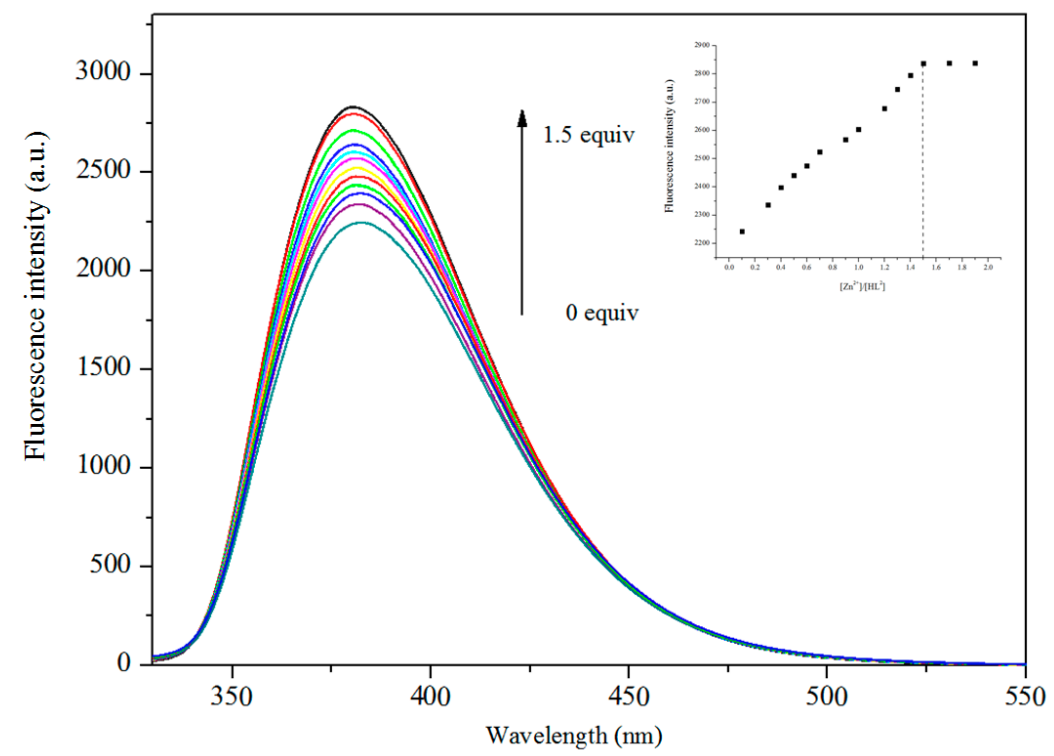

Figure 9. Absorption spectra of $\mathrm{HL}^{2}$ in DMF solutions upon the addition of $\mathrm{Zn}^{2+}$. Inset: The absorbance at $380 \mathrm{~nm}$ varied as an interaction of $\left[\mathrm{Zn}^{2+}\right] /\left[\mathrm{HL}^{2}\right]$.

The free ligand $\mathrm{H}_{2} \mathrm{~L}^{1}$ appears as an intense emission peak at $432 \mathrm{~nm}$. With the fluorescence titration experiment, upon the addition of $\mathrm{Zn}^{2+}$, gradual changes in the fluorescence spectra. And the fluorescence intensity increased significantly. When the added amount of $\mathrm{Zn}^{2+}$ reached 1.0 equiv., the fluorescence emission intensity became stable, which indicates a 1:1 stoichiometry between $\mathrm{Zn}^{2+}$ and $\mathrm{H}_{2} \mathrm{~L}^{1}$. The enhancement of fluorescence is due to the coordination of metal ions with ligands [67]. Likewise, Complex 2 displays enhanced emission intensities compared to the corresponding ligand $\left(\mathrm{HL}^{2}\right)$ when excited at $380 \mathrm{~nm}$. When the added amount of $\mathrm{Zn}^{2+}$ reached 1.5 equiv., the fluorescence emission intensity became steady. The result is corresponding to the crystal structure of complex 2 [68].

For research the solvent effect in fluorescence spectra of complexes $\mathbf{1}$ and 2, the fluorescence spectra of complex $\mathbf{1}$ and $\mathbf{2}$ in a series of solvents were examined and are shown in Table 7 and Figures 10 and 11. 
Table 7. The maximum fluorescence emission in difference solvents for complexes $\mathbf{1}$ and 2.

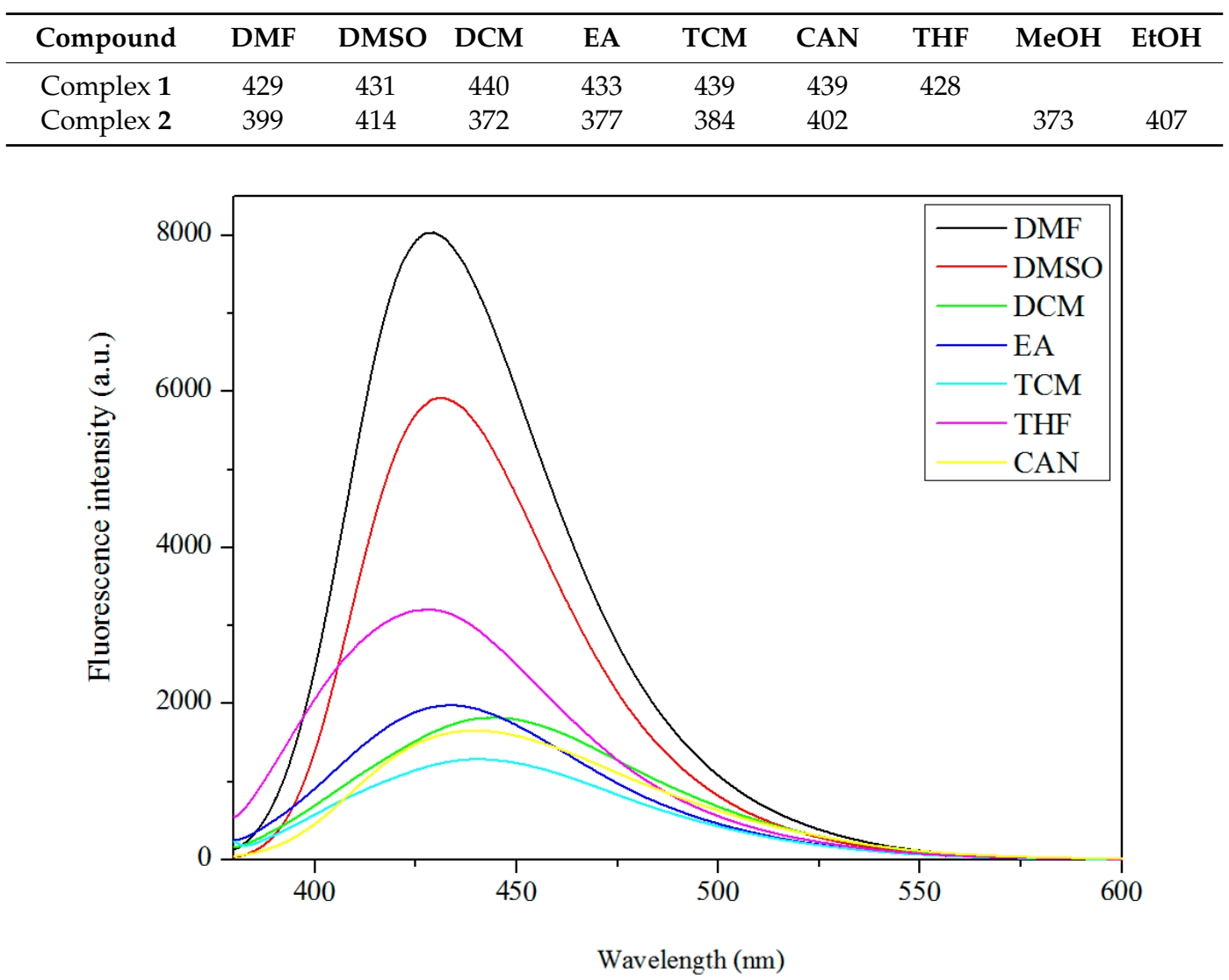

Figure 10. The fluorescent $\left(\lambda_{\text {ex }}=370 \mathrm{~nm}\right)$ spectra of complex $1\left(2.5 \times 10^{-5} \mathrm{M}\right)$ in various solvents.

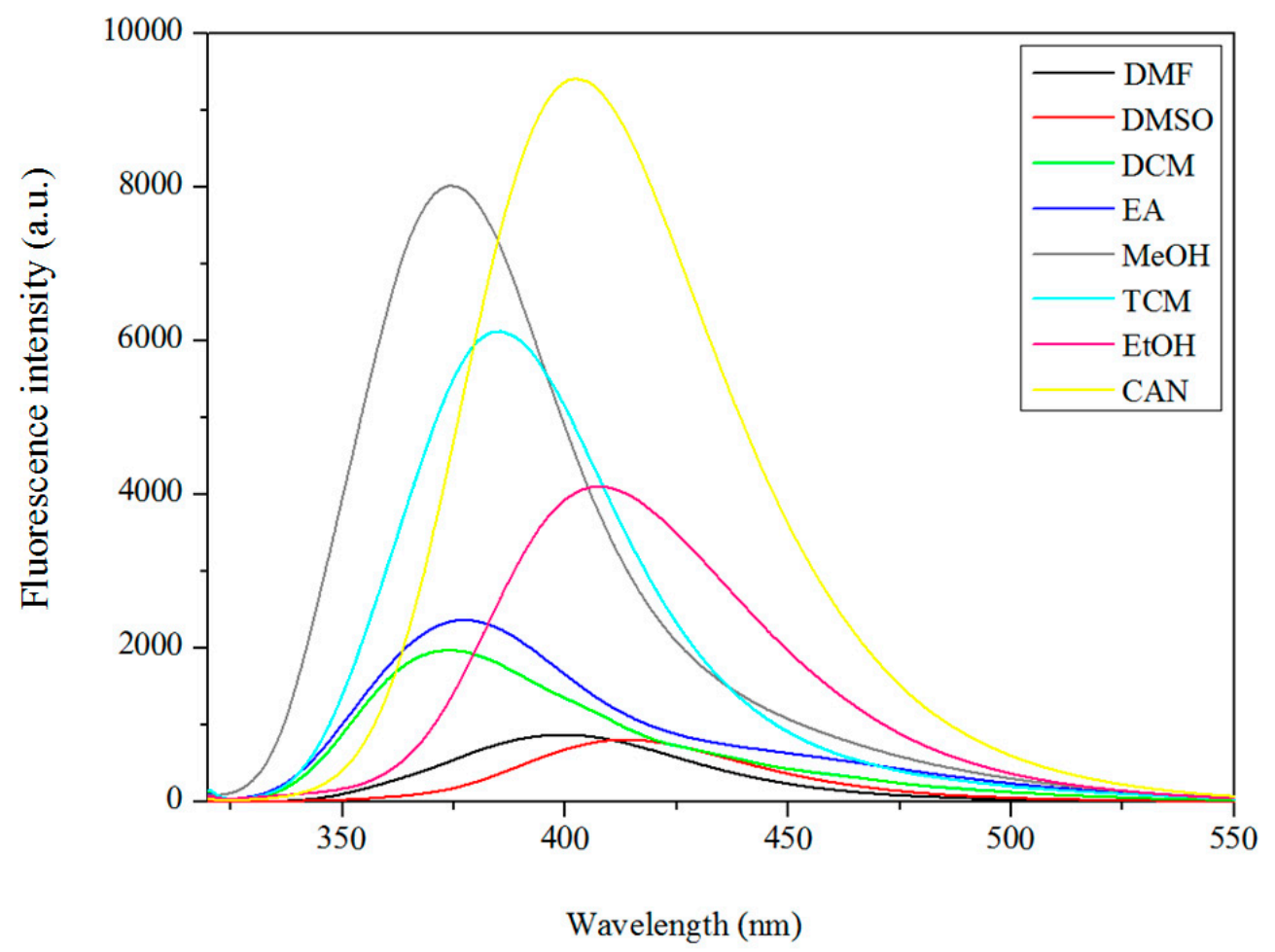

Figure 11. The fluorescent $\left(\lambda_{\mathrm{ex}}=315 \mathrm{~nm}\right)$ spectra of complex $2\left(2.5 \times 10^{-5} \mathrm{M}\right)$ in various solvents. 
The normalized fluorescent spectra of complexes $\mathbf{1}$ and $\mathbf{2}$ are shown in Figures 12 and 13. Additionally, the fluorescence image of complexes $\mathbf{1}$ and $\mathbf{2}$ upon irradiation with a $365 \mathrm{~nm}$ UV lamp also indicated that the metal complexes $\mathbf{1}$ and $\mathbf{2}$ have promising applications as fluorescent materials. The solvent effect brings pivotal effect to the photoluminescence of complexes $\mathbf{1}$ and $\mathbf{2}$.

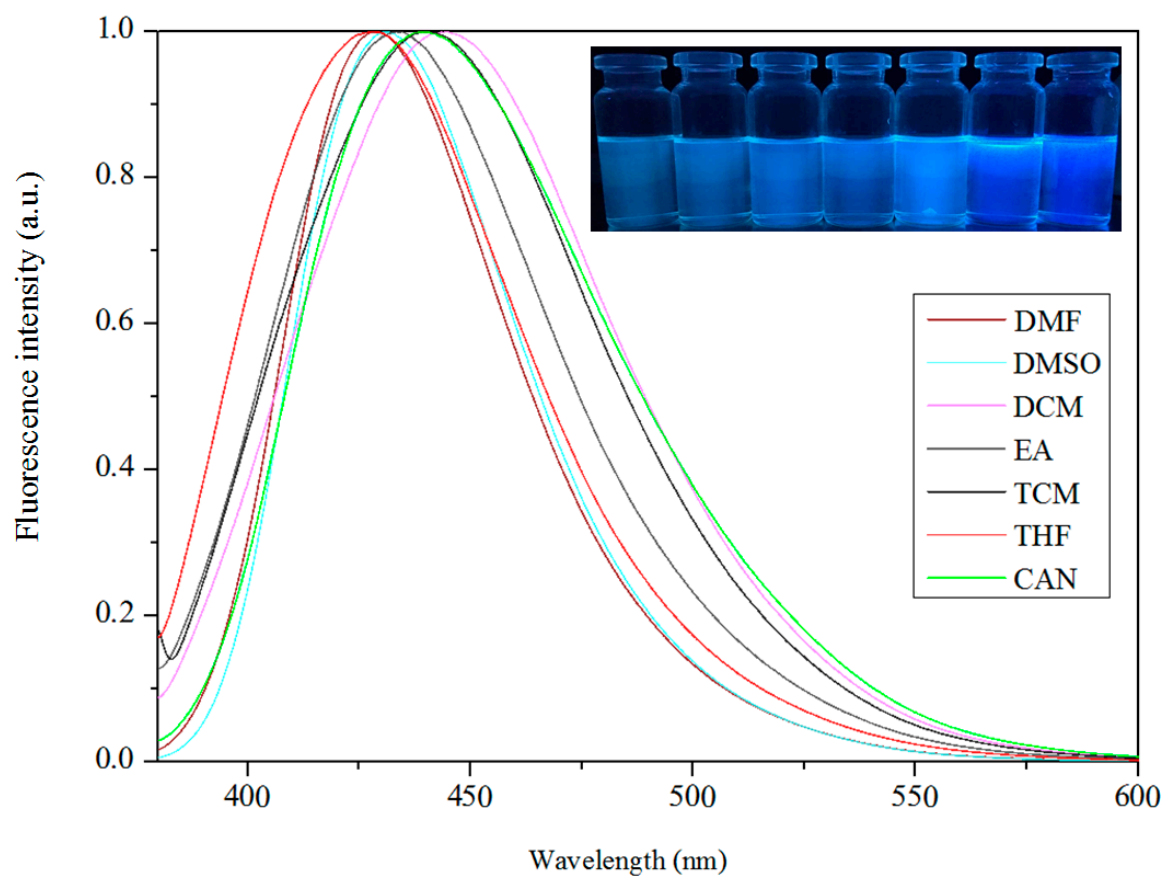

Figure 12. The normalized fluorescent spectra of complex 1. Inset image: the fluorescence picture of complex 1 in various solvents upon irradiation with a $365 \mathrm{~nm}$ UV lamp.

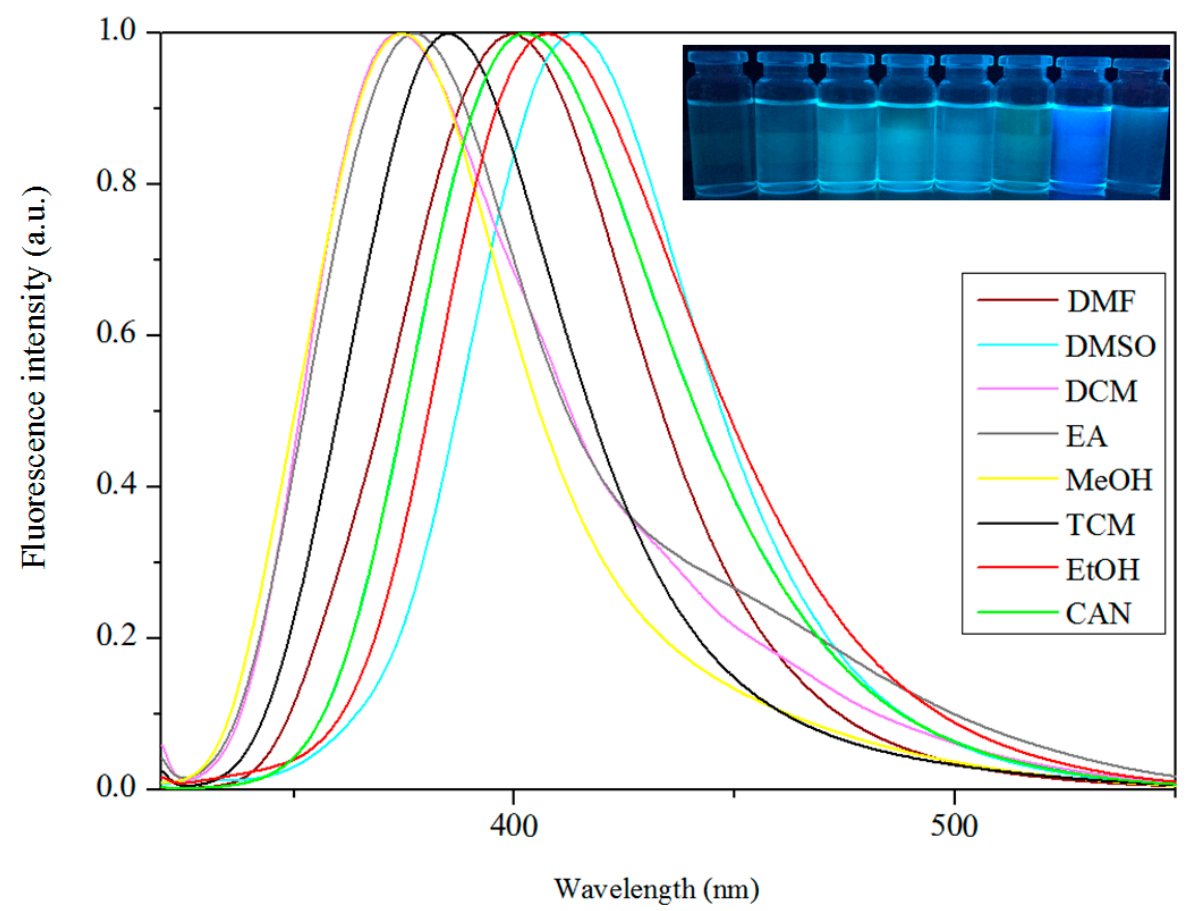

Figure 13. The normalized fluorescent spectra of complex 2. Inset image: the fluorescence picture of complex 1 in various solvents upon irradiation with a $365 \mathrm{~nm}$ UV lamp. 
As we know, many fluorescent complexes, especially those containing polar substituents on aromatic rings, are susceptible to solvents [27]. Due to the difference in polarity of solvents, complex 1 exhibits the relatively strong maximum fluorescence emission with relatively low solvent polarity in TCM and DCM at 439 and $440 \mathrm{~nm}$, respectively. Additionally, in solvents THF, DMF, and DMSO with higher solvent polarity, the maximum fluorescence emission is relatively weak at 428,429 , and $431 \mathrm{~nm}$, respectively. In solvents of medium polarity, EA and CAN, the maximum fluorescence emission was at 433 and $439 \mathrm{~nm}$, respectively. Meanwhile, complex 2 exhibits the relatively strong maximum fluorescence emission with relatively high solvent polarity in DMF, CAN, EtOH, and DMSO at 399, 402,407 , and $414 \mathrm{~nm}$, respectively. In solvents DCM, TCM, and EA with lower solvent polarity, the maximum fluorescence emission is relatively weak at 372,384 and $377 \mathrm{~nm}$, respectively. Furthermore, the maximum fluorescence emission unusually appears at $373 \mathrm{~nm}$ in $\mathrm{MeOH}$ solvent. The influence of the solvent effect changes the luminescent properties of complexes $\mathbf{1}$ and $\mathbf{2}$, making its application areas broad $[27,69]$.

\section{Conclusions}

In summary, we have reported the successful syntheses and characterizations of two newly-designed complexes, $\left[\mathrm{Zn}\left(\mathrm{L}^{1}\right)(\mathrm{EtOH})\right](\mathbf{1})$ and $\left[\left\{\mathrm{Zn}\left(\mathrm{L}^{2}\right)(\mathrm{OAc})_{2}\right\}_{2} \mathrm{Zn}\right] \cdot \mathrm{CHCl}_{3}(\mathbf{2})$, derived from salamo and half-salamo chelating ligands $\left(\mathrm{H}_{2} \mathrm{~L}^{1}\right.$ and $\left.\mathrm{HL}^{2}\right)$. Complex 1 includes one $\mathrm{Zn}(\mathrm{II})$ ion, one completely deprotonated $\left(\mathrm{L}^{1}\right)^{2-}$ unit and one coordinated ethanol molecule, which shows a slightly distorted trigonal bipyramidal geometry and forms an infinite 3D supramolecular structure. Complex 2 includes three $\mathrm{Zn}(\mathrm{II})$ ions, two completely deprotonated $\left(\mathrm{L}^{2}\right)^{1-}$ moieties, four coordinated acetate ions, and possesses an infinite 2D space structure. The normalized fluorescent spectra exhibit that complexes 1 and $\mathbf{2}$ have favourable fluorescent emissions in different solvents.

Acknowledgments: This work was supported by the National Natural Science Foundation of China (21361015, 21761018), the Outstanding Research Platform (Team), and the Graduate Student Guidance Team Building Fund of Lanzhou Jiaotong University (260001), which are gratefully acknowledged.

Author Contributions: Wen-Kui Dong and Lei Gao conceived and designed the experiments; Fei Wang performed the experiments; Yang Zhang analyzed the data; Wen-Kui Dong contributed reagents/materials/analysis tools; Xiu-Yan Dong wrote the paper.

Conflicts of Interest: The authors declare no competing financial interests.

\section{References}

1. Dong, W.K.; Lan, P.F.; Zhou, W.M.; Zhang, Y. Salamo-type trinuclear and tetranuclear cobalt(II) complexes based on a new asymmetry salamo-type ligand: Syntheses, crystal structures and fluorescence properties. J. Coord. Chem. 2016, 65, 1272-1283. [CrossRef]

2. Dong, X.Y.; Akogun, S.F.; Zhou, W.M.; Dong, W.K. Tetranuclear Zn(II) complex based on an asymmetrical Salamo-type chelating ligand: Synthesis, structural characterization, and fluorescence property. J. Chin. Chem. Soc. 2017, 64, 412-419. [CrossRef]

3. Tao, C.H.; Ma, J.C.; Zhu, L.C.; Zhang, Y.; Dong, W.K. Heterobimetallic 3d-4f Zn(II)-Ln(III) (Ln = Sm, Eu, $\mathrm{Tb}$ and $\mathrm{Dy}$ ) complexes with a $\mathrm{N}_{2} \mathrm{O}_{4}$ bisoxime chelate ligand and a simple auxiliary ligand Py: Syntheses, structures and luminescence properties. Polyhedron 2017, 128, 38-45. [CrossRef]

4. $\quad$ Dong, Y.J.; Dong, X.Y.; Dong, W.K.; Zhang, Y.; Zhang, L.S. Three asymmetric Salamo-type copper(II) and cobalt(II) complexes: Syntheses, structures, fluorescent properties. Polyhedron 2017, 123, 305-315. [CrossRef]

5. Dong, W.K.; Ma, J.C.; Dong, Y.J.; Zhao, L.; Zhu, L.C.; Sun, Y.X.; Zhang, Y. Two hetero-trinuclear Zn(II)-M(II) $(\mathrm{M}=\mathrm{Sr}, \mathrm{Ba})$ complexes based on metallohost of mononuclear $\mathrm{Zn}(\mathrm{II})$ complex: Syntheses, structures and fluorescence properties. J. Coord. Chem. 2016, 69, 3231-3241. [CrossRef]

6. Wu, H.L.; Wang, C.P.; Wang, F.; Peng, H.P.; Zhang, H.; Bai, Y.C. A new manganese(III) complex from bis(5-methylsalicylaldehyde)-3-oxapentane-1,5-diamine: Synthesis, characterization, antioxidant activity and luminescence. J. Chin. Chem. Soc. 2015, 62, 1028-1034. [CrossRef] 
7. Wu, H.L.; Bai, Y.C.; Zhang, Y.H.; Li, Z.; Wu, M.C.; Chen, C.Y.; Zhang, J.W. Synthesis, crystal structure, antioxidation and DNA-binding properties of a dinuclear copper(II) complex with bis(N-salicylidene)-3oxapentane-1, 5-diamine. J. Coord. Chem. 2014, 67, 3054-3066. [CrossRef]

8. Wu, H.L.; Bai, Y.; Yuan, J.K.; Wang, H.; Pan, G.L.; Fan, X.Y.; Kong, J. A zinc(II) complex with tris(2-(N-methyl) benzimidazlylmethyl)amine and salicylate: Synthesis, crystal structure, and DNA-binding. J. Coord. Chem. 2012, 65, 2839-2851. [CrossRef]

9. Wu, H.L.; Pan, G.L.; Wang, H.; Wang, X.L.; Bai, Y.C.; Zhang, Y.H. Study on synthesis, crystal structure, antioxidant and DNA-binding of mono-, di- and poly-nuclear lanthanides complexes with bis(Nsalicylidene)-3-oxapentane-1,5-diamine. J. Photochem. Photobiol. B Biol. 2014, 135, 33-43. [CrossRef] [PubMed]

10. Wu, H.L.; Bai, Y.C.; Zhang, Y.H.; Pan, G.L.; Kong, J.; Shi, F.; Wang, X.L. Two lanthanide(III) complexes based on the schiff base $\mathrm{N}, \mathrm{N}$-Bis(salicylidene)-1,5-diamino-3-oxapentane: Synthesis, characterization, DNA-binding properties, and antioxidation. Z. Anorg. Allg. Chem. 2014, 640, 2062-2071. [CrossRef]

11. Wu, H.L.; Pan, G.L.; Bai, Y.C.; Wang, H.; Kong, J.; Shi, F.; Zhang, Y.H.; Wang, X.L. Preparation, structure, DNA-binding properties, and antioxidant activities of a homodinuclear erbium(III) complex with a pentadentate Schiff base ligand. J. Chem. Res. 2014, 38, 211-217. [CrossRef]

12. Wu, H.L.; Pan, G.L.; Bai, Y.C.; Wang, H.; Kong, J. Synthesis, structure, antioxidation, and DNA-bindingstudies of a binuclear ytterbium(III) complex with bis(N-salicylidene)-3-oxapentane-1,5-diamine. Res. Chem. Intermed. 2015, 41, 3375-3388. [CrossRef]

13. Chen, C.Y.; Zhang, J.W.; Zhang, Y.H.; Yang, Z.H.; Wu, H.L. Gadolinium(III) and dysprosium(III) complexes with a Schiff base bis( $N$-salicylidene)-3-oxapentane-1,5-diamine: Synthesis, characterization, antioxidation, and DNA-binding studies. J. Coord. Chem. 2015, 68, 1054-1071. [CrossRef]

14. Dong, W.K.; Ma, J.C.; Zhu, L.C.; Zhang, Y.; Li, X.L. Four new nickel(II) complexes based on an asymmetric Salamo-type ligand: Synthesis, structure, solvent effect and electrochemical property. Inorg. Chim. Acta 2016, 445, 140-148. [CrossRef]

15. Chai, L.Q.; Zhang, K.Y.; Tang, L.J.; Zhang, J.Y.; Zhang, H.S. Two mono- and dinuclear ni(II) complexes constructed from quinazoline-type ligands: Synthesis, x-ray structures, spectroscopic, electrochemical, thermal, and antimicrobial studies. Polyhedron 2017, 130, 100-107. [CrossRef]

16. Yu, T.Z.; Zhang, K.; Zhao, Y.L.; Yang, C.H.; Zhang, H.; Qian, L.; Fan, D.W.; Dong, W.K.; Chen, L.L.; Qiu, Y.Q. Synthesis, crystal structure and photoluminescent properties of an aromatic bridged Schiff base ligand and its zinc complex. Inorg. Chim. Acta 2008, 361, 233-240. [CrossRef]

17. Dong, Y.J.; Ma, J.C.; Zhu, L.C.; Dong, W.K.; Zhang, Y. Four 3d-4f heteromultinuclear zinc(II)-lanthanide(III) complexes constructed from a distinct hexadentate $\mathrm{N}_{2} \mathrm{O}_{2}$-type ligand: Syntheses, structures and photophysical properties. J. Coord. Chem. 2017, 70, 103-115. [CrossRef]

18. Wang, L.; Ma, J.C.; Dong, W.K.; Zhu, L.C.; Zhang, Y. A novel Self-assembled nickel(II)-cerium(III) heterotetranuclear dimer constructed from $\mathrm{N}_{2} \mathrm{O}_{2}$-type bisoxime and terephthalic acid: Synthesis, structure and photophysical properties. Z. Anorg. Allg. Chem. 2016, 642, 834-839. [CrossRef]

19. Dong, W.K.; Chen, X.; Sun, Y.X.; Yang, Y.H.; Zhao, L.; Xu, L.; Yu, T.Z. Synthesis, structure and spectroscopic properties of two new trinuclear nickel(II) clusters possessing solvent effect. Spectrochim. Acta Part A 2009, 74, 719-725. [CrossRef] [PubMed]

20. Dong, W.K.; Li, G.; Wang, Z.K.; Dong, X.Y. A novel trinuclear cobalt(II) complex derived from an asymmetric Salamo-type $\mathrm{N}_{2} \mathrm{O}_{3}$ bisoxime chelate ligand: Synthesis, structure and optical properties. Spectrochimica Acta Part A 2014, 133, 340-347. [CrossRef] [PubMed]

21. Liu, Y.A.; Wang, C.Y.; Zhang, M.; Song, X.Q. Structures and magnetic properties of cyclic heterometallic tetranuclear clusters. Polyhedron 2017, 127, 278-286. [CrossRef]

22. Dong, W.K.; Ma, J.C.; Dong, Y.J.; Zhu, L.C.; Zhang, Y. Di-and tetranuclear heterometallic 3d-4f cobalt(II)-lanthanide(III) complexes derived from a hexadentate bisoxime: Syntheses, structures and magnetic properties. Polyhedron 2016, 115, 228-235. [CrossRef]

23. Song, X.Q.; Liu, P.P.; Xiao, Z.R.; Li, X.; Liu, Y.A. Four polynuclear complexes based on a versatile salicylamide salen-like ligand: Synthesis, structural variations and magnetic properties. Inorg. Chim. Acta 2015, 438, 232-244. [CrossRef]

24. Liu, P.P.; Wang, C.Y.; Zhang, M.; Song, X.Q. Pentanuclear sandwich-type $\mathrm{Zn}^{\mathrm{II}}$-Ln ${ }^{\mathrm{III}}$ clusters based on a new Salen-like salicylamide ligand: Structure, near-infrared emission and magnetic properties. Polyhedron 2017, 129, 133-140. [CrossRef] 
25. Dong, W.K.; Ma, J.C.; Zhu, L.C.; Zhang, Y. Nine self-assembled nickel(II)-lanthanide(III) heterometallic complexes constructed from a Salamo-type bisoxime and bearing $\mathrm{N}$ - or O-donor auxiliary ligand: Syntheses, structures and magnetic properties. New J. Chem. 2016, 40, 6998-7010. [CrossRef]

26. Dong, W.K.; Ma, J.C.; Zhu, L.C.; Zhang, Y. Self-assembled zinc(II)-lanthanide(III) heteromultinuclear complexes constructed from 3-MeOsalamo ligand: Syntheses, structures and luminescent properties. Cryst. Growth Des. 2016, 16, 6903-6914. [CrossRef]

27. Chen, L.; Dong, W.K.; Zhang, H.; Zhang, Y.; Sun, Y.X. Structural variation and luminescence properties of triand dinuclear $\mathrm{Cu}^{\mathrm{II}}$ and $\mathrm{Zn}^{\mathrm{II}}$ complexes constructed from a naphthalenediol-based bis(Salamo)-type ligand. Cryst. Growth Des. 2017, 17, 3636-3648. [CrossRef]

28. Song, X.Q.; Peng, Y.J.; Chen, G.Q.; Wang, X.R.; Liu, P.P.; Xu, W.Y. Substituted group-directed assembly of $\mathrm{Zn}(\mathrm{II})$ coordination complexes based on two new structural related pyrazolone based Salen ligands: Syntheses, structures and fluorescence properties. Inorg. Chim. Acta. 2015, 427, 13-21. [CrossRef]

29. Dong, W.K.; Zhang, J.; Zhang, Y.; Li, N. Novel multinuclear transition metal(II) complexes based on an asymmetric Salamo-type ligand: Syntheses, structure characterizations and fluorescent properties. Inorg. Chim. Acta. 2016, 444, 95-102. [CrossRef]

30. Dong, W.K.; Akogun, S.F.; Zhang, Y.; Dong, X.Y. A reversible "turn-on" fluorescent sensor for selective detection of $\mathrm{Zn}^{2+}$. Sensors Actuators B Chem. 2017, 238, 723-734. [CrossRef]

31. Dong, Y.J.; Li, X.L.; Zhang, Y.; Dong, W.K. A highly selective visual and fluorescent sensor for $\mathrm{Pb}^{2+}$ and $\mathrm{Zn}^{2+}$ and crystal structure of $\mathrm{Cu}^{2+}$ complex based-on a novel single-armed Salamo-type bisoxime. Supramol. Chem. 2017, 29, 518-527. [CrossRef]

32. Dong, W.K.; Li, X.L.; Wang, L.; Zhang, Y.; Ding, Y.J. A new application of Salamo-type bisoximes: as a relay-sensor for $\mathrm{Zn}^{2+} / \mathrm{Cu}^{2+}$ and its novel complexes for successive sensing of $\mathrm{H}^{+} / \mathrm{OH}^{-}$. Sens. Actuators B Chem. 2016, 229, 370-378. [CrossRef]

33. Zhao, L.; Dang, X.T.; Chen, Q.; Zhao, J.X.; Wang, L. Synthesis, crystal structure and spectral properties of a 2D supramolecular copper(II) complex with 1-(4-\{[(E)-3-ethoxyl-2-hydroxybenzylidene]amino\}phenyl)ethanone oxime. Synth. React. Inorg. Met. -Org. Nano-Met. Chem. 2013, 43, 1241-1246. [CrossRef]

34. Sun, Y.X.; Xu, L.; Zhao, T.H.; Liu, S.H.; Liu, G.H.; Dong, X.T. Synthesis and crystal structure of a 3D supramolecular copper(II) complex with 1-(3-\{[(E)-3-bromo-5-chloro-2-hydroxybenzylidene]amino\}phenyl) ethanone oxime. Synth. React. Inorg. Met. -Org. Nano-Met. Chem. 2013, 43, 509-513. [CrossRef]

35. Sun, Y.X.; Dong, W.K.; Wang, L.; Zhao, L.; Yang, Y.H. Synthesis and crystal structure of nickel(II) cluster with salen-type bisoxime ligand. Chinese J. Inorg. Chem. 2009, 25, 1478-1482.

36. Sun, Y.X.; Zhang, S.T.; Ren, Z.L.; Dong, X.Y.; Wang, L. Synthesis, characterization, and crystal structure of a new supramolecular $\mathrm{Cd}^{\mathrm{II}}$ complex with halogen-substituted salen-type bisoxime. Synth. React. Inorg. Met.-Org. Nano-Met Chem. 2013, 43, 995-1000. [CrossRef]

37. Dong, W.K.; Zhang, X.Y.; Zhao, M.M.; Li, G.; Dong, X.Y. Syntheses and crystal structures of 5-Methoxy-6'-hydroxy-2,2'-[ethylenedioxybis(nitrilomethylidyne)]diphenol and its tetranuclear zinc(II) complex. Chin. J. Inorg. Chem. 2014, 30, 710-716.

38. Zhou, J.A.; Tang, X.L.; Cheng, J.; Ju, Z.H.; Yang, L.Z.; Liu, W.S.; Chen, C.Y.; Bai, D.C. An 13,4-oxadiazole-based off-on fluorescent chemosensor for $\mathrm{Zn}^{2+}$ in aqueous solution and imaging application in living cells. Dalton Trans. 2012, 41, 10626-10632. [CrossRef] [PubMed]

39. Akine, S.; Taniguchi, T.; Dong, W.K.; Masubuchi, S.; Nabeshima, T. Oxime-Based Salen-Type Tetradentate Ligands with High Stability against Imine Metathesis Reaction. J. Org. Chem. 2005, 70, 1704-1711. [CrossRef] [PubMed]

40. Akine, S.; Dong, W.K.; Nabeshima, T. Octanuclear zinc(II) and cobalt(II) clusters produced by cooperative tetrameric assembling of oxime chelate ligands. Inorg. Chem. 2006, 454, 677-4684. [CrossRef] [PubMed]

41. Song, X.Q.; Cheng, G.Q.; Liu, Y.A. Enhanced Tb(III) luminescence by $\mathrm{d}^{10}$ transition metal coordination. Inorg. Chim. Acta 2016, 450, 386-394. [CrossRef]

42. Darensbourg, D.J.; Karroonnirun, O.; Wilson, S.J. Ring-Opening Polymerization of Cyclic Esters and Trimethylene Carbonate Catalyzed by Aluminum Half-Salen Complexes. Inorg. Chem. 2011, 50, 6775-6787. [CrossRef] [PubMed]

43. Darensbourg, D.J.; Karroonnirun, O. Stereoselective Ring-Opening Polymerization of rac-Lactides Catalyzed by Chiral and Achiral Aluminum Half-Salen Complexes. Organometallics 2010, 29, 5627-5634. [CrossRef] 
44. Dong, Y.; Li, F.J.; Jiang, X.X.; Song, F.Y.; Cheng, Y.X.; Zhu, C.J. Na triggered fluorescence sensors for $\mathrm{Mg}^{2+}$ detection based on a coumarin salen moiety. Org. Lett. 2011, 9, 2252-2255. [CrossRef] [PubMed]

45. Dong, W.K.; Wang, Z.K.; Li, G.; Zhao, M.M.; Dong, X.Y.; Liu, S.H. Syntheses, crystal structures, and properties of a Salamo-type tetradentate chelating ligand and its pentacoordinated copper(II) complex. Z. Anorg. Allg. Chem. 2013, 639, 2263-2268. [CrossRef]

46. Dong, W.K.; Feng, J.H.; Yang, X.Q. Synthesis and crystal structure of a five-coordinated cu(II) dimer with 4,4'-Dibromo-2,2'-[ethylenedioxybis(nitrilomethylidyne)]diphenol. Synth. React. Inorg. Met. Org. Nano Met. Chem. 2007, 37, 189-192. [CrossRef]

47. Ma, J.C.; Dong, X.Y.; Dong, W.K.; Zhang, Y.; Zhu, L.C.; Zhang, J.T. An unexpected dinuclear Cu(II) complex with a bis(Salamo) chelating ligand: synthesis, crystal structure, and photophysical properties. J. Coord. Chem. 2016, 69, 149-159. [CrossRef]

48. Sheldrick, G.M. SHELXS-97. In Program for the Solution and the Refinement of Crystal Structures; University of Gottingen: Germany, 1997.

49. Dong, W.K.; Zhang, F.; Li, N.; Xu, L.; Zhang, Y.; Zhang, J.; Zhu, L.C. Trinuclear cobalt(II) and zinc(II) salamo-type complexes: Syntheses, crystal structures, and fluorescent properties. Z. Anorg. Allg. Chem. 2016, 642, 532-538. [CrossRef]

50. Dong, W.K.; Zhang, L.S.; Sun, Y.X.; Zhao, M.M.; Li, G.; Dong, X.Y. Synthesis, crystal structure and spectroscopic properties of a supramolecular zinc(II) complex with $\mathrm{N}_{2} \mathrm{O}_{2}$ coordination sphere. Spectrochim. Acta Part A 2014, 121, 324-329. [CrossRef] [PubMed]

51. Hao, J.; Li, L.H.; Zhang, J.T.; Akogun, S.F.; Wang, L.; Dong, W.K. Four homo- and hetero-bismetallic 3d/3d-2s complexes constructed from a naphthalenediol-based acyclic bis(salamo)-type tetraoxime ligand. Polyhedron 2017, 134, 1-10. [CrossRef]

52. Li, L.H.; Dong, W.K.; Zhang, Y.; Akogun, S.F.; Xu, L. Syntheses, structures and catecholase activities of homo-and hetero-trinuclear cobalt(II) complexes constructed from an acyclic naphthalenediol-based bis(salamo)-type ligand. Appl. Organomet. Chem. [CrossRef]

53. Addison, A.W.; Rao, T.N.; Reedijk, J.; van Rijn, J.; Verschoor, G.C. Synthesis, structure, and spectroscopic properties of copper(II) compounds containing nitrogen-sulphur donor ligands; the crystal and molecular structure of aqua[1,7-bis(N-methylbenzimidazol-2'-yl)-2,6-dithiaheptane]copper(II) perchlorate. J. Chem. Soc. Dalton Trans. 1984, 7, 1349-1356. [CrossRef]

54. Konno, T.; Tokuda, K.; Sakurai, J.; Okamoto, K.I. Five-Coordinate Geometry of Cadmium(II) with Octahedral Bidentate-S,S Complex-Ligand cis(S)-[Co(aet)2(en)]+ (aet = 2-aminoethanethiolate): Synthesis, Crystal Structures and Interconversion of S-Bridged CoIIICdII Polynuclear Complexes. Bull. Chem. Soc. Jpn. 2000, 73, 2767-2773. [CrossRef]

55. Chai, L.Q.; Tang, L.J.; Chen, L.C.; Huang, J.J. Structural, spectral, electrochemical and DFT studies of two mononuclear manganese(II) and zinc(II) complexes. Polyhedron 2017, 122, 228-240. [CrossRef]

56. Xu, L.; Zhu, L.C.; Ma, J.C.; Zhang, Y.; Zhang, J.; Dong, W.K. Syntheses, structures and spectral properties of mononuclear $\mathrm{Cu}^{\mathrm{II}}$ and dimeric $\mathrm{Zn}^{\mathrm{II}}$ complexes based on an asymmetric Salamo-type $\mathrm{N}_{2} \mathrm{O}_{2}$ ligand. Z. Anorg. Allg. Chem. 2015, 641, 2520-2524. [CrossRef]

57. Boggs, J.M. Lipid intermolecular hydrogen bonding: influence on structural organization and membrane function. Biochim. Biophys. Acta 1987, 906, 353-404. [CrossRef]

58. Karas, L.J.; Batista, P.R.; Viesser, R.V.; Tormena, C.F.; Rittner, R.; de Oliveira, P.R. Trends of intramolecular hydrogen bonding in substituted alcohols: a deeper investigation. Phys. Chem. Chem.Phys. 2017, 19, 16904-16913. [CrossRef] [PubMed]

59. Mathias, J.P.; Simanek, E.E.; Whitesides, G.M. Self-Assembly through Hydrogen Bonding: Peripheral Crowding-A new strategy for the preparation of stable supramolecular aggregates based on parallel, connected CA3.cntdot.M3 rosettes. J. Am. Chem. Soc. 1994, 116, 4326-4340.

60. Yabuuchi, K.; Marfo-Owusu, E.; Kato, T. A new urea gelator: incorporation of intra- and intermolecular hydrogen bonding for stable 1D self-assembly. Org. Biomol. Chem. 2003, 1, 3464-3469. [CrossRef] [PubMed]

61. Chai, L.Q.; Huang, J.J.; Zhang, J.Y.; Li, Y.X. Two 1-D and 2-D cobalt(II) complexes: Synthesis, crystal structures, spectroscopic and electrochemical properties. J. Coord. Chem. 2015, 68, 1224-1237. [CrossRef]

62. Sun, Y.X.; Wang, L.; Dong, X.Y.; Ren, Z.L.; Meng, W.S. Synthesis, characterization, and crystal structure of a supramolecular $\mathrm{Co}^{\mathrm{II}}$ complex containing Salen-type bisoxime. Synth. React. Inorg. Met.-Org. Nano-Met. Chem. 2013, 43, 599-603. [CrossRef] 
63. Wang, P.; Zhao, L. Synthesis and crystal structure of supramolecular copper(II) complex based on $\mathrm{N}_{2} \mathrm{O}_{2}$ coordination Sphere. Asian J. Chem. 2015, 4, 1424-1426. [CrossRef]

64. Liu, P.P.; Sheng, L.; Song, X.Q.; Xu, W.Y.; Liu, Y.A. Synthesis, structure and magnetic properties of a new one dimensional manganese coordination polymer constructed by a new asymmetrical ligand. Inorg. Chim. Acta 2015, 434, 252-257. [CrossRef]

65. Wang, B.J.; Dong, W.K.; Zhang, Y.; Akogun, S.F. A novel relay-sensor for highly sensitive and selective detection of $\mathrm{Zn}^{2+} / \mathrm{Pic}^{-}$and fluorescence on/off switch response of $\mathrm{H}^{+} / \mathrm{OH}^{-}$. Sens. Actuators B Chem. 2017, 247, 254-264. [CrossRef]

66. Akine, S.; Morita, Y.; Utsuno, F.; Nabeshima, T. Multiple folding structures mediated by metal coordination of acyclic multidentate ligand. Inorg. Chem. 2009, 48, 10670-10678. [CrossRef] [PubMed]

67. Song, X.Q.; Liu, P.P.; Liu, Y.A.; Zhou, J.J.; Wang, X.L. Two dodecanuclear heterometallic $\left[\mathrm{Zn}_{6} \operatorname{Ln}_{6}\right]$ clusters constructed by a multidentate salicylamide salen-like ligand: Synthesis, structure, luminescence and magnetic properties. Dalton Trans. 2016, 45, 8154-8163. [CrossRef] [PubMed]

68. Guo, C.Y.; Wang, Y.Y.; Xu, K.Z.; Zhu, H.L.; Liu, P.; Shi, Q.Z. Crystal structures, bioactivities and fluorescent properties of four diverse complexes with a new symmetric benzimidazolic ligand. Polyhedron 2008, 27, 3529-3536. [CrossRef]

69. Che, G.B.; Liu, C.B.; Liu, B.; Wang, Q.W.; Xu, Z.L. Syntheses, structures and photoluminescence of a series of metal-organic complexes with 1,3,5-benzenetricarboxylate and pyrazino[2,3-f][1,10]-phenanthroline ligands. Cryst. Eng. Commun. 2008, 10, 184-191. [CrossRef]

(C) 2017 by the authors. Licensee MDPI, Basel, Switzerland. This article is an open access article distributed under the terms and conditions of the Creative Commons Attribution (CC BY) license (http://creativecommons.org/licenses/by/4.0/). 